
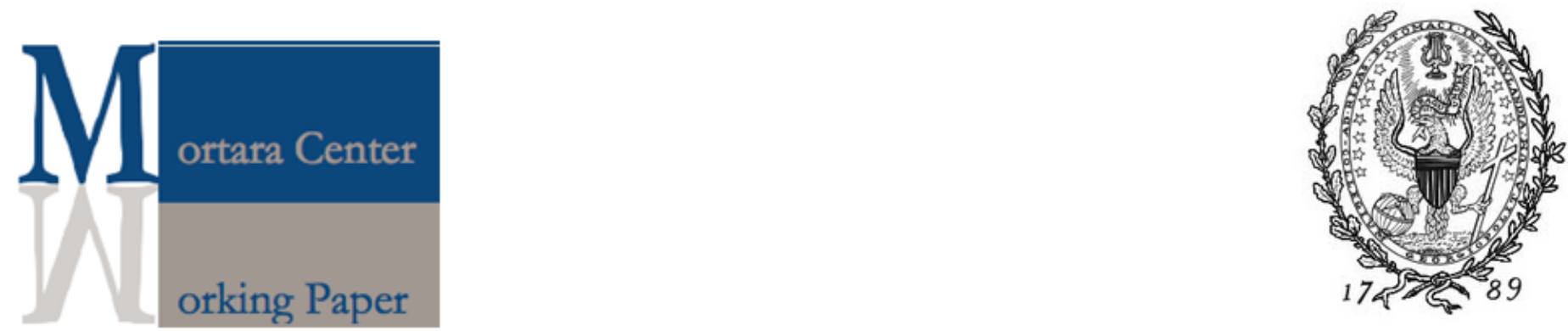

Interest Coalitions and Multilateral Aid Allocation in the European Union

Christina J. Schneider

University of California, San Diego

Jennifer L. Tobin

Georgetown University 


\title{
Interest Coalitions and Multilateral Aid Allocation in the European Union*
}

\author{
CHRISTINA J. SCHNEIDER \\ University of California, San Diego
}

JENNIFER L. TOBIN

Georgetown University

\begin{abstract}
This paper analyzes multilateral aid allocation in the European Union (EU). We argue that EU members can influence the aid allocation process towards their national interests if they form powerful coalitions that bias the European Commission's development policies. When EU members' preferences over aid allocation are heterogeneous, the Commission can implement multilateral aid according to its programmatic goals. Greater homogeneity of EU members' goals, however, increases the likelihood that members can form powerful interest coalitions, and induce the Commission to allocate aid according to their own national interests. The empirical analysis provides robust support for our theoretical argument and the findings generally indicate that interest coalitions play an important role in multilateral aid allocation.
\end{abstract}

\footnotetext{
*Authors' note: We thank Marc Busch, Mark Copelovitch, Christian Dippel, Simon Hug, Robert Hutchings, Joe Jupille, Katharina Michaelowa, Helen Milner, Dan Nielsen, Richard Nielson, Willem Schudel, Branislav Slantchev, Randy Stone, Mike Tierney, Dustin Tingley, Johannes Urpelainen, Erik Voeten, Jim Vreeland, Nick Weller, Joseph Wright, and the participants of seminars at the Colorado European Union Center of Excellence, Princeton University, Georgetown University, University of Virginia, as well as participants of the Political Economy of International Organizations (PEIO) workshop for their helpful comments on earlier drafts of the paper. The paper was presented at the International Studies Association conference, the Midwest Political Science Association conference in 2009, and PEIO in 2010. Schneider gratefully acknowledges financial support from the UC Berkeley European Union Center of Excellence. A replication package can be found in the ISQ data archive.
} 


\section{"The European Union is firmly committed to the Millennium Development Goals and is working hard to eradicate poverty and improve living conditions by 2015."}

-José Barroso, President of the EU Commission, 2010

\section{INTRODUCTION}

In September 2000 the European Union (EU), together with 192 members of the United Nations and over 23 international organizations, committed itself to the Millennium Development Goals, a plan to reduce extreme poverty by 2015 . Recent poverty estimates from the World Bank show that many regions have made great progress towards that goal. Yet, the report paints a less rosy picture for Sub-Saharan Africa, where economic growth is most desperately needed and where the least amount of progress has been made. One reason for the lack of development in Africa can be found in the dynamics of foreign aid allocation. Donor governments have been criticized for allocating their bilateral foreign aid according to their national strategic interests rather than addressing the economic and institutional needs of the poorest countries in the world. ${ }^{1}$ And although observers and policy-makers have praised multilateral aid institutions as more objective aid-givers who tend to allocate aid according to

1 Whereas strategic aid focuses on the economic development needs of those recipient countries in which the donor has a national political, military, or commercial interest, development aid focuses on the development priorities of those countries most in need, be that from a human development or economic perspective. The principle of development aid is nowadays explicitly linked to the principle that aid should be allocated to economically deprived countries that utilize aid effectively even though the research on how institutional quality affects aid effectiveness tends to be fragile (Easterly et al. 2004). 
development needs, recent research indicates that multilateral aid allocation, including the multilateral aid provided through the EU institutions, exhibits similar biases with detrimental effects on development outcomes (Stone 2002, 2008, 2010; Nielson and Tierney 2003; Copelovitch 2010).

To understand some of the obstacles to economic development in these poor countries, we must first understand the decision-making processes that allow donor governments to exert influence over the multilateral aid allocation process. ${ }^{2}$ This paper analyzes decision-making outcomes on multilateral aid policies within the EU by taking into account the interrelationship between intergovernmental and supranational actors. We argue that EU members delegate foreign aid allocation to the European Commission to increase the efficiency with which aid is allocated, but that these benefits crucially depend on whether the Commission allocates the aid in accordance with the individual EU member's foreign aid preferences (whether they be strategic or development based). EU members thus aim to influence the Commission to shift aid allocation towards their own national interests. Members can assert themselves in the decision-making process and put pressure on the Commission either if they are individually powerful or if they form powerful coalitions in the intergovernmental bargaining process. The more homogenous the preferences of EU member states, the greater their ability to form influential coalitions, and the more likely that European aid allocation will be biased in favor of members' own interests. If the preferences of EU members diverge, however, then the Commission increases its ability to play member states

2 Our paper focuses on the ability of EU members to influence who gets European aid. Another interesting aspect is the ability of EU members to influence how European aid is allocated. For example, EU members and the Commission may have diverging preferences over aid conditionality. In the conclusion, we will discuss to what extent our findings provide a foundation for a theory on the politics of multilateral aid conditionality. 
against each other and to implement its official development goals, which emphasize the poorest countries in the world.

To test our argument, we compile a data set with observations on EU multilateral aid allocations to the developing world from 1973 to 2006 . We determine the power of interest coalitions in the Council negotiations, by developing an indicator that measures the strength of EU member states' interest in a specific recipient country, weighted by the EU members' bargaining power in the Council. The quantitative analysis robustly supports our theoretical arguments. Although powerful states are able to bias the multilateral aid allocation process individually, they are not alone in their ability to do so. If states can form powerful coalitions they can bias the multilateral aid allocation process away from the EU's official development goals. Greater heterogeneity increases the ability of the Commission to pursue its development interests, but at the same time limits the financial resources to do so.

Our paper provides the first application of the collective principal model to the European Union. Most of the empirical work on power politics in international institutions has focused on analyzing either political processes within the IMF and the World Bank (with a focus on US influence) or specific aid projects (i.e. environmental or social aid) across a group of multilateral development banks. There has been no in-depth analysis of the politics of European aid, even though the EU is now the largest multilateral aid donor in the world, allocating more resources than even the World Bank. ${ }^{3}$ The implications of European aid allocation politics for developing countries are therefore very important. At the same time, our findings are of more general interest for scholars who analyze decision-making outcomes in multilateral aid institutions. ${ }^{4}$ Whereas our paper builds on the important insights of collective

3 See also Figure 2. These figures do not include bilateral aid from EU member states. If we take bilateral aid into account, then the EU is the largest donor in the world relative to bilateral and multilateral donors.

4 The decision-making process within the EU is similar to that of regional and multilateral aid institutions, 
principal theory (Nielson and Tierney 2003), it also expands this theory in two important ways. First, our theory can explain the strong findings on dominant donors in multilateral aid institutions, but it also explicitly analyzes the influence of coalition formation on multilateral aid allocation (and provides a measure for interest coalitions that is easily applied to other multilateral aid institutions, individual aid sectors, or specific donor groups). ${ }^{5}$ Second, our empirical findings provide new insights into the consequences of agency slippage. On one hand, whereas scholars have emphasized the negative effects of agency slippage, our findings indicate that agency slippage may also have positive effects because it increases the ability of the multilateral agency to provide aid that is consistent with the goal of sustainable economic development. On the other hand, we find that although agency slippage increases the ability of the agent to implement its preferred policies, it also decreases its ability to expand its resources to pursue these objectives. This stands in contrast to traditional models that assume that heterogeneity of principals' preferences leads to an expansion of the agent's budget. As we show, in situations in which principals can decide on the amount of delegation to the agent, agency slippage does not necessarily lead to budgetary expansions.

where the multilateral aid agent implements aid policies, but is controlled by an intergovernmental body which has to decide by some majority.

5 To the best of our knowledge, Lyne et al. (2009) is the only published paper that empirically analyzes all possible coalitions within multilateral aid institutions. Our paper differs from theirs in three important respects. First, whereas Lyne et al. (2009) focus on the influence of coalitions on social lending, our paper focuses on the allocation of multilateral aid more general. Second, Lyne et al. (2009) provide an empirical analysis of coalitions and find no great power influence on social lending (indeed, social lending seems to contradict US preferences). Our theory (supported by our empirical test) indicates that both great power and coalitions matter. Finally, whereas their model focuses on the influence of governments, we also model the agent as a strategic actor. We therefore provide a comprehensive model of the politics of multilateral aid allocation that incorporates all these different theoretical arguments. See also Nielson and Tierney (2010) for an application to environmental lending. 


\section{THE PUZZLE}

The allocation of foreign aid through multilateral aid agencies has become increasingly popular since the late 1960s and 1970s. Figure 1 illustrates this trend by graphing total multilateral official development aid (ODA) contributions in constant (2008) millions of US\$ as well as multilateral delegation as a percentage of all multilateral contributions from 23 OECD donor countries to a sample of 26 multilateral aid agencies and development banks from 1970 to 2008. During this period, the amount of foreign aid spent through multilateral aid institutions more than tripled to over 30 billion US dollars. At the same time, contributions to multilateral donors has gone up and down and varies greatly across donors. Currently, donor countries on average spend about 35 per cent of their foreign aid through multilateral channels, a substantial amount, given public perceptions about how multilateral aid is spent.

[Figure 1 about here]

Incentives to delegate foreign aid to multilateral aid institutions have been particularly pronounced in the European Union. EU members have not only decided to coordinate their bilateral aid efforts more thoroughly, but they have steadily increased the amount of foreign aid given through the European Commission. In 2008, EU members spent 17 per cent of their foreign aid through the European Union (and 37 per cent through multilateral aid institutions more generally). EU multilateral aid rests on three pillars - the common EU budget, the European Development Fund (EDF), and the European Investment Bank (EIB)—and accounts for about 13.9 per cent of all developing aid in the world (almost $60 \%$ if one takes into account bilateral aid from EU members). ${ }^{6}$ This unprecedented increase in contributions has made the EU the largest multilateral aid donor in the world and the third largest donor overall after the United States and Germany. For example, Figure 2 illustrates how the

\footnotetext{
6 EU budget aid and EDF aid mainly provide grants whereas the EIB's main function is to provide loans.
} 
European Union has exceeded the World Bank as the largest multilateral aid donor in the world.

[Figure 2 about here]

Scholars and observers alike have welcomed these developments. The primary rationale behind delegating substantial management and agenda-setting powers to the EU is that the European Commission, which manages European aid projects, can exploit its independence and information advantages to diffuse strategic interests and to ensure a more developmentbased approach to foreign aid. ${ }^{7}$ However, the theoretical predictions of this hand-tying argument have not found consistent support in empirical applications of European aid allocation. Rather, scholars find a consistent and dominant effect of EU member interests on the allocation of European aid (Tsoutsoplides 1991; Zanger 2000; Kostadinova 2009; Baumann et al. 2010). These findings present a puzzle to the theoretical literature on European aid-giving: If the Commission ties the EU members' hands when it comes to allocation policies why, or under which conditions, do EU members have an influence on allocation outcomes?

We address this question by analyzing EU decision-making on multilateral aid policies taking into account the relationships among EU governments and the European Commission. Our theory is based on the important insights of collective principal theory which stipulates that decision-making outcomes in international institutions should be affected by the relationship between the group of member states (the principals) and the organizational agent (Nielson and Tierney 2003; Hawkins et al. 2006). Extant collective principal theory provides two important insights. First, multilateral aid tends to follow the interests of the most powerful member countries, particularly if their interests converge (Schoultz 1982; Thacker 1999; Stone

7 Rodrik (2005) provides a general theoretical basis for this argument. 
2002, 2004, 2008; Nielson and Tierney 2003, 2010; Faini and Grilli 2004; Copelovitch 2010).

Second, if the preferences of the most dominant donors diverge, then the multilateral agent will be able to pursue its own interests by implementing its preferred policies and providing greater loans and grants (Nielson and Tierney 2003; Hawkins et al. 2006; Copelovitch 2010).

Our theory extends these theories by modeling intergovernmental decision-making such that all EU members can influence the Commission, and therefore aid allocation, if they form interest coalitions with EU members that share similar aid policies to their own. ${ }^{8}$ Indeed, if we follow the historical debates about European aid allocation, there is much evidence of the formation of such interest coalitions that lobbied for particular aid policies in the Council. ${ }^{9}$ For example, France and Belgium formed a coalition before an EU development policy was even established, hoping to focus development policy on their former African colonies. Their interests clashed with those of Germany and the Netherlands which lobbied in favor of a more global and humanitarian approach to EU development policy. ${ }^{10}$ The accession of nine new members between 1972 and 1995 led to a dramatic increase in heterogeneity among members with regards to the goals of EU development policy. The United Kingdom, for example, wanted to include its former colonies in Africa, Asia, and the Caribbean. The Mediterranean countries, on the other hand, formed a coalition to support the inclusion of Latin America, and the Nordic countries aligned with Germany and Denmark to promote a more general humanitarian approach to development. Interest heterogeneity declined drastically following the unexpected fall of the Soviet Union beginning in 1989. Most members expected great

8 Lyne et al. (2009) provide an empirical analysis of interest coalitions on social lending in multilateral development banks. See FN 4 for a discussion of similarities and differences between their and our approach.

9 For an excellent historical analysis of European multilateral aid see Grilli (1993).

10France and Belgium had an advantageous bargaining position because they credibly threatened to withdraw cooperation and forced other member states to comply with their interests. 
benefits from concentrating aid on the countries of Central and Eastern Europe (CEE). Not only did the integration of markets lead to higher interdependence in Europe, but West European states also had strong commercial interests in developing the CEE thanks to new opportunities in trade and investment. With this convergence of interests, EU governments, together, were able to influence the direction of EU aid towards the CEE and away from the original mandate of the agency towards needs based development. The numbers bear this out, with EU multilateral aid in the 2000s favoring transition countries in Eastern Europe, while crowding out aid to Sub-Saharan Africa. ${ }^{11}$ Our theory acknowledges that these opportunities exist and models how the interaction between EU members and the European Commission can affect multilateral aid allocation, particularly if the preferences of individual EU members diverge from the EU's programmatic goals.

\section{THEORY}

This section develops a theory of the politics of European aid allocation. In a nutshell, we argue that even though EU members benefit from delegating aid to the EU, these benefits depend on their ability to influence the Commission so as to bias the allocation of multilateral aid in favor of their own development goals. We show that EU members are able to exert influence if their preferences align with other EU members so that they can form powerful coalitions that overcome the collective action problems within the intergovernmental bargaining process. However, as EU members' preferences towards European aid allocation become more heterogeneous it will become more difficult to form coalitions, and the Commission can play different interests against each other to pursue its programmatic goals.

Our theory focuses on explaining the allocation of EU multilateral aid, which excludes the bilateral aid of its member states. Multilaterally, the EU has two main programs that provide

11 Results of both a quantitative and more in-depth qualitative study are available from the authors. 
grants in order to promote sustainable economic development. ${ }^{12}$ The first program, coordinated through the Directorate General (DG) of EuropeAid Development and Cooperation, is integrated into and financed by the common EU budget. ${ }^{13}$ The second program, through the European Development Fund (EDF), allows governments to provide development assistance outside of the common EU budget. Both programs are managed by the European Commission. The main difference is that the European Parliament only has influence over the programs that are funded by the EU budget. The decision-making process in the EU concerning European aid allocation is very similar to the decision-making processes within the regional and multilateral development banks, where the multilateral aid agent implements aid policies, but is controlled by an intergovernmental body which reaches decisions by some type of majority rule. Whereas the European Commission controls European aid allocations as the multilateral agent, it is the EU member states that decide on overall aid policy, based on goals formulated in the acquis communautaire (the common body of rules and norms). EU members decide by qualified majority, which provides opportunities for coalition formation. ${ }^{14}$

Our theory is based on two basic assumptions. First, the Commission, which manages

12 In addition to the programs discussed here, the EIB provides some concessional loans, but most of its funding for concessional loans comes from the EDF and is earmarked. Consequently, decisions over grants—which we analyze empirically because these are actually paid-in contributions - are decided by the EU member states.

13 The DG EuropeAid used to be divided into the DG EuropeAid and the DG Development. The DG of External Relations is also involved in the Commission's development policies.

14 EU budget aid decisions are made within the Council of Ministers; EDF aid decisions are made within the EDF Committee. Both bodies are comprised of all EU member states, with vote shares highly dependent on each member's gross domestic product. In both for a, EU members decide by qualified majority. We will therefore treat them as similar. 
European aid as the agent of the EU members, has intrinsic incentives to provide aid based on economic development needs and/or good governance principles (March and Olson 1988; Copelovitch 2010). Background information on the Commission reflects these incentives relatively well. EU staff is almost principally composed of economists and civil servants with no domestic political objectives or ties to national governments. In fact, the EU explicitly prohibits the selection of staff members based on nationality or for the fulfillment of national quotas. For the most part, therefore, the Commission itself has defended the interests of the poorest countries against the interests of member states in shifting aid policies towards wealthier regions (Carbone 2007). In doing so it has been able to largely rely on Article 177, the official development goals of the EU, which focuses on the development of the poorest countries in the world with a special focus on African countries. Even if the Commission was interested primarily in the survival and growth of its organization, agent slippage would reinforce this needs-based approach (Vaubel 1996, 2006; Frey 1997). That is, the Commission will try to maximize its staff, budget, and mandate, but in pursuing its development goals it is restricted by its reputation on the domestic level. If it loses its reputation as an agency focusing on the economic development of the poorest regions in the world, it would lose its reason for existence.

Second, delegation of foreign aid to the EU increases the value of aid provided. On one hand, governments benefit because delegation to the EU implies burden sharing of development efforts. In many cases, governments are not able or willing to individually solve more complex problems like HIV/AIDS. When pooling resources, EU governments can lower their individual costs of providing such public goods without having to compromise on their overall goals. Delegation also provides opportunities to influence the aid allocation decisions of other EU member states through the intergovernmental process. The more powerful the EU member is in asserting its position in the EU, the greater the expected gains from burden 
sharing. On the other hand, the Commission controls an aid budget which is larger than the individual donations of its members. Whereas the bulk of resources come from public funds in EU member states, EU multilateral aid programs receive additional funding from capital markets (for those resources that are dedicated to loans through, for example, the EDF's Investment Facility) or from the public and private sector. For example, the European Investment Fund (EIB) contributes additional resources to the EDF from its own resources which are raised on capital markets. In addition, both the Commission programs and the EDF engage in co-financing with the EIB, nongovernmental organizations, EU members, as well as third-party countries (EU Commission 2002). This increases the overall resources that are managed by the EU, thus multiplying the operational budgets that EU members are able to control. At the same time, by pooling the administrative apparatus, the EU significantly decreases administrative and organizational costs. Overall, the whole is greater than the sum of its parts: by delegating, EU governments can increase the value of development aid that would have been given bilaterally; they can do more with less.

These delegation gains are only valuable for an EU member, however, if the Commission's allocation of aid mirrors the EU member's preferences over foreign aid allocation. For example, Germany has been very active in providing economic development in the Central and Eastern European countries. Consequently, providing aid through the EU would be particularly valuable for Germany if it focused on the development of this region. The benefits from delegation would be worthless, on the other hand, if the EU focused its aid projects in other regions. Because even efficient aid-giving is not very beneficial to an EU member if European aid is not allocated according to that member's interests, individual EU governments try to shift allocation decisions at the European level as close as possible to their ideal policies.

EU member states can influence the Commission's allocation decisions through the 
intergovernmental decision-making process. If a majority of EU members agree to change allocation policies in the Council, then the Commission has to implement these changes. The amount of influence an individual EU member exerts in the intergovernmental bargaining process depends therefore on its interests regarding European aid allocation relative to the interests of other EU member states as well as its bargaining power. The most straightforward case in which an EU member state can influence European allocation decisions is if it is powerful enough either to assert itself in Council negotiations or to influence the Commission individually. The greater the decision-making power of individual EU member states, the less important are coalition partners with similar preferences, and the easier it is for an EU member to assert its individual preferences. Such bargaining power can come from a country's vote share or its ability to use its domestic resources to provide side-payments to other EU members with different preferences. Germany and France have been considered dominant players in the EU, not just because of their large vote shares, but also because of their ability to informally influence negotiations. This leads to our first testable empirical implication: ${ }^{15}$

\section{Hypothesis 1a: If a dominant EU member favors a recipient country (for strategic or} other reasons), that recipient will receive more EU multilateral aid.

Dominance of one EU member state is not the only way to bias multilateral aid allocation, however. As EU member states' preferences about European aid allocation become more homogenous, opportunities for coalition formation arise. When this is the case, the likelihood of imposing its preferences depends on how the member's preferences align with others. The more homogenous the preferences of EU member states about specific policies, regardless of whether these preferences are strategic- or development-based or both, the easier it is to form

15 This result accounts for what scholars have found for the influence of US interests within the World Bank and the IMF. Given its bargaining power, the United States has been able to repeatedly influence loan conditions and sanctions to the benefit of recipients when it was in the United States' national interest. 
coalitions and to overcome existing majority hurdles. The Commission cannot insulate itself from government preferences if a majority of states aim to implement similar policies. For example, Belgium, France, and the United Kingdom formed a coalition and asserted their desire to increase aid to their former colonies without the support of other member states. Consequently, EU members, weak and powerful alike, can influence the allocation of multilateral aid if they belong to a group of states with homogenous preferences that is sufficiently large enough to fulfill the majority requirements:

\section{Hypothesis 1b: If a powerful interest coalition of EU members favors a recipient} country (for strategic or other reasons), that recipient will receive more EU multilateral aid.

Thus, powerful individual members or coalitions of members are able to influence the allocation of multilateral aid away from the interests of the Commission, leading to multilateral aid that is less focused on organizational goals and more focused on the interests of the member states (if these interests diverge from the official goals).

Coalition formation becomes increasingly difficult when EU members' preferences diverge. When preferences of EU members during negotiations are largely heterogeneous, the Commission may even be able to play members against each other. If EU member states disagree over whether proposed policy changes are feasible, then the Commission can use the uncertainty of negotiations and its own expert knowledge to implement policies that accord with its goals (or to implement status quo policies). In other words, as long as a majority of EU members disagree that a potential policy falls within the scope of the EU's goals, they cannot change the distributional rules. This has two important empirical implications. First, we expect that as the heterogeneity of EU members' interests increases, the influence of coalitions' interests on the allocation of EU multilateral aid declines: 
Hypothesis 2a: As the heterogeneity of EU member preferences increases, coalitions of member states will be less likely to influence the allocation of EU multilateral aid.

In other words, we expect the relationship of Hypothesis $1 \mathrm{~b}$ to weaken. Second, whereas intergovernmental influence over multilateral aid allocation should decline with increased heterogeneity, we predict an increase in the Commission's ability to determine the allocation of multilateral aid. But what effect does this have on who gets multilateral aid? If - as assumed above - the Commission aims to implement the EU's official development goals, then greater heterogeneity of EU member preferences would imply that the Commission can use its increased leverage to allocate aid according to economic need and principles of good governance:

Hypothesis 2b: As the heterogeneity of EU member preferences increases, countries with greater development needs are more likely to receive EU multilateral aid.

In sum, the ability of EU governments to bias the allocation of multilateral aid depends on the homogeneity of EU members' interests and the bargaining power of emerging interest coalitions within the EU. The ability to overcome collective action problems amongst EU member states is most difficult when preferences towards aid allocation are heterogeneous. We hypothesize that when EU member preferences are heterogeneous, aid allocation will increase the ability of the EU Commission to pursue the EU's programmatic goals. However, if interest coalitions form, then EU aid allocation will depend on the coalitions' interests even if no dominant member state exists. Developing countries that have a strong support coalition within the Council should receive greater aid from the EU independent of its economic needs, ceteris paribus. 


\section{EMPIRICAL ANALYSIS}

This section provides a test of our theoretical hypotheses. The empirical analysis focuses on EU multilateral aid allocation (excluding any bilateral aid from EU member states as well as EU structural and cohesion funds) to developing countries. We use a data set with observations on multilateral aid from the EU to 146 recipient countries over the period 1977 $2006 .{ }^{16}$ The unit of analysis is the recipient-year.

\section{DEPENDENT VARIABLE}

The dependent variable, EC Aid Receipts, is measured as the log of multilateral ODA commitments from the European Commission to all low- and middle-income countries (in constant 2000 US dollars), as reported in the OECD's International Development Statistics. ${ }^{17}$ We chose this operationalization over other methods of measuring aid receipts, such as aid as a percent of total aid or aid as a function of population or income per capita because we are interested in how aid is allocated to recipients. In other words, we want to measure the "gross importance" of the given recipient country to the EU. The level of European aid is the most direct measure of that concept. Nevertheless, we account for population and income measures as right hand side variables and we substitute our dependent variable with aid per capita and aid as a percentage of recipient GDP in our robustness checks where we continue to find support for our results.

16 This includes all recipient countries in the OECD database considered "developing" by the OECD.

17 This includes EU budget aid, EDF aid, and EIB's concessional aid. 


\section{INDEPENDENT VARIABLES}

Our theoretical argument focuses on two components within the European decisionmaking process that affect European aid allocation: the formation of interest coalitions (Hypotheses $1 \mathrm{a}$ and $\mathrm{b}$ ) and the heterogeneity of preferences (Hypotheses $2 \mathrm{a}$ and $2 \mathrm{~b}$ ).

Interest Coalition measures the strength of EU member states' interest in a specific recipient country, weighted by the EU members' bargaining power in the Council. To construct this measure we proceed in three steps. First, we measure the saliency of foreign aid interests for each EU member state relying on the well-documented research that shows that bilateral foreign aid reflects a donor state's interest in providing multilateral aid to a developing country (Maizels and Nissanke 1984; Schraeder et al. 1998; Alesina and Dollar 2000; Stone 2002, 2004, 2008). ${ }^{18}$ Bilateral aid is most appropriate as a measure of EU member interests in Council negotiations because it accounts for all dimensions of donor interests, particularly strategic and development aid. By using bilateral aid we do not have to make assumptions about whether a donor is more interested in economic development or in supporting its geo-political and military goals, but can rather acknowledge that donors typically pursue both goals (to varying degrees) at the same time. ${ }^{19}$ Theoretically, we expect

18 One problem with this assumption could be that governments may gain from delegation because the multilateral aid institution provides aid for other reasons, that is bilateral and multilateral aid are complementary (i.e. to recipients/projects/areas not favored by the donor's bilateral aid). In this case, we would expect that interest coalition would be negatively related to European aid flows (since powerful coalitions would induce the Commission to give aid to other countries). Our empirical results suggest that bilateral aid is actually a good measure for EU members' interests in European aid allocation.

19 One potential problem with this approach is that bilateral aid can be influenced by decisions made about EU multilateral aid. For example, if multilateral aid is provided to support environmental policies, donors could use bilateral aid for other types of projects. As a robustness check we used bilateral aid as percentage of total 
that EU members aim to assert both strategic and development interests in the Council and both should therefore be reflected in European aid allocation. Of course, it could be that EU members' ability to assert themselves is different depending on whether they are pursuing strategic or development interests. In the robustness section, we will use two alternative measures for interest saliency that allow us to distinguish between the two types of aid-giving. Neither provides substantially different results. We derive the basic aid allocation interests of any EU bilateral donor $i$ in any given recipient $j$ by taking each donor's bilateral aid flows to the recipient, as a proportion of that donor's population for each year $t$ :

$$
\text { Interest }_{i, j, t}=\frac{\text { Aid }_{i, j, t}}{\text { Population }_{i, t}}
$$

Increasing values for Interest imply that an EU member has increasingly salient interests in providing multilateral aid to that country. We use population of the EU member in the denominator to account for the fact that smaller countries often tend to concentrate their bilateral aid on a few countries rather than to give small amounts of aid to many countries. ${ }^{20}$

In a second step, we weigh the saliency of interests by the EU member's bargaining power in the Council of Ministers (data from European Union). ${ }^{21}$ Bargaining power is measured as each EU member's Council vote as a proportion of total votes in the Council. Whereas a member's vote share mainly accounts for its formal bargaining power, it is also highly

bilateral aid flows and we also controlled for the total amount of multilateral aid receipts (exclusive of EU multilateral aid). Neither of these estimations had a significant impact on our results.

20 Our results do not change substantively if we use gross domestic product or total aid in the denominator.

21 Note, decisions about the EDF are made within the EDF committee which represents all EU member states and is chaired by the Commission. Unfortunately, the OECD does not provide separate data for EDF and EU budget aid. We use Council vote shares because both Council and EDF committee vote shares are highly correlated with a country's GDP. We expect very similar findings if we used EDF vote shares instead. 
correlated with measures of informal bargaining power such as income, population, military strength or historical importance:

$$
\text { Power }_{i, t}=\frac{\text { Vote }_{i, t}}{\sum_{i=1}^{N} \text { Vote }_{i, t}}
$$

We now have information on each EU member's interest saliency in a recipient and its formal bargaining power. To examine the impact of any individual donor on EU aid flows to recipients, we combine Interest and Power for that donor. To test our hypothesis on dominant donor influence (Hypothesis 1a), we analyze the individual influence of Germany and France (the two most dominant members of the EU) on multilateral aid flows:

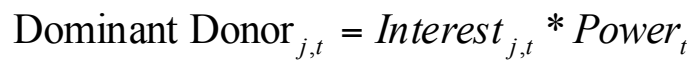

Dominant Donor measures, for each aid recipient, the saliency of German (or French) interest weighted by German (or French) voting power in the Council. To test our hypothesis on coalition formation (Hypothesis 1b), we combine our measures of Interest and Power, and aggregate them across Council members. The value of Interest Coalition for a given recipient country $j$ in any given year $t$ is calculated as:

$$
\text { Interest Coalition }_{j, t}=\sum_{i=1}^{N}\left(\text { Interest }_{i, j, t} * \text { Power }_{i, t}\right)
$$

The variable Interest Coalition thus represents the EU Council's interest salience in a specific recipient. In accordance with our theory, we expect that the stronger a developing country's support within the EU Council (in terms of saliency and power), the greater its multilateral EU aid receipts.

[Figure 3 about here]

[Figure 4 about here] 
Figure 3 illustrates our measure by examining changes in interest coalitions averaged by region over time. In line with the scholarly findings discussed above, in the early 1990s, a strong interest coalition in favor of providing aid to European recipients emerged. This falls in line with the end of the Cold War and the increasing strategic importance of Central and Eastern Europe in the 1990s. Similarly, support for European aid to Asia dramatically increased beginning in the late 1980s, which relates back to the increasing importance of India and China (especially of late). Interest coalitions for Africa and Latin America have been relatively flat, but within each region we observe a great deal of variation both across and within countries. Figure 4 graphs Interest Coalition for four African countries: Congo, D.R. (a former Belgian colony), Ghana (a former British colony), Mozambique (a former Portuguese colony), and Niger (a former French Colony). Mozambique, a relatively poor country, had almost no support within the Council until around 2000. Since then, Council support has increased dramatically, most likely coinciding with its second democratic election and the relative political stability the country has experienced since the elections. Ghana and Congo D.R. have had relatively rocky support coalitions, with large variations throughout (though both experienced a significant downswing in the 1980s). Finally, Niger's support has been relatively stable, though decreasing from the late 1980s onward.

Heterogeneity measures the heterogeneity of aid allocation interests across EU member states in the Council for each year. To measure Heterogeneity, we calculate the coefficient of variation, which is the ratio of the standard deviation to the mean, expressed as a percentage, of EU members' interest saliency in each year of observation. ${ }^{22}$ We expect that the greater the heterogeneity of interests among EU members, the less important interest coalitions for multilateral aid allocation (Hypothesis 2a), and the more European aid will be distributed to poor countries (Hypothesis 2b).

22 We thank Mark Copelovitch for his input on how to measure heterogeneity. 
To test Hypothesis 2b, we also need a measure for the recipient countries' development needs. We use the log of gross domestic product (GDP) per capita in constant (2000) U.S. dollars as main indicator for development need (data from World Bank Development Indicators). Per Capita GDP is the most commonly used and relied upon measure of need in the literature on aid. We would prefer to include measures of human development to further account for development need, but including these variables would result in a significant loss of data, mainly from the poorest countries, thereby biasing our empirical results. Nevertheless, we are confident that Per Capita GDP provides a good approximation not only because of its wide use across the aid literature, but because of its high correlation with measures of human development such as infant mortality and literacy (Easterly and Dollar 1999).

\section{CONTROL VARIABLES}

Our choice of control variables was guided by the relevant empirical literature on aid allocation decisions cited above. Institutional quality is nowadays intrinsically linked to providing development-based aid. We control for the quality of democratic institutions (Institutional Quality) using data from Polity IV (Marshall et al. 2009). ${ }^{23}$ To assess strategic economic interests we include Imports from $E U$ which is measured as the natural log of all imports in a given year a recipient country has from the EU. Data are from World Bank's World Integrated Trade Solution Database. Since our data set spans from 1974 to 2006, and aid strategies changed drastically during and after the Cold War, we control for this time period. Post Cold War takes the value 0 prior to 1989 and 1 in 1989 and after. ${ }^{24}$ Distance measures the natural log of the geographic distance (in kilometers) between a given country and Brussels. Data are from Gleditsch and Ward (2001). We further use a dummy variable

23 We provide an alternative measure of institutional quality in the robustness section.

24 The results do not change substantively if we use 1991 as the watershed year instead. 
equal to 1 if a country has ever been a colony of a member of the EU and a 0 otherwise (Colony) and we control for the natural log of a country's population in a given year (Population). Data are from the World Bank Development Indicators. To account for emergency aid allocations to countries that experience natural disasters, we include the sum of deaths in the country per year due to natural disasters (Natural Disaster Deaths). Data are from the EM-DAT International Disaster Database. We control for the change in total aid receipts (EU Aid Change) because a change in multilateral aid receipts could be the result of a change in the total amount of aid. For example, overall aid flows from the EU may decrease as a result of donor fatigue or the may increase as a result of agency slippage. Finally, we include the lag of our dependent variable, a set of regional dummies, and a time trend. Table 1 presents descriptive statistics.

[Table 1 about here]

\section{SPECIFICATION}

Our econometric specification takes the following linear form: EU multilateral aid to recipient $j$ in year $t$ depends on the $\log$ of EU aid in year $t-1$, coalition support (or dominant donor) in recipient $j$ (Interest Coalition), interest heterogeneity among EU members (Heterogeneity), the level of a recipient's development needs (Per Capita GDP), control variables (Control), and an error term $(\varepsilon)$ :

$$
\begin{aligned}
\text { EC Aid Receipts }(\log )_{j, t} & =\alpha+\beta_{1} \text { EC Aid Receipts }(\log )_{j, t-1}+\beta_{2} \text { Interest Coalition }_{j, t} \\
+ & \beta_{3} \text { Heterogeneity }_{j, t}+\beta_{4} \text { Per Capita GDP }(\log )_{j, t}+\beta_{7} \text { Controls }_{j, t}+\varepsilon_{j, t}
\end{aligned}
$$

According to Hypothesis 1a, recipients favored by dominant donors should receive greater aid receipts, ceteris paribus $\left(\beta_{2}>0\right)$. We test this hypothesis for the effect of the dominant $\mathrm{EU}$ members, Germany and France. Hypothesis $1 \mathrm{~b}$ states that recipients favored by powerful interest coalitions will receive greater aid receipts, ceteris paribus $\left(\beta_{2}>0\right)$. To evaluate 
Hypotheses $2 \mathrm{a}$ and $2 \mathrm{~b}$, we include an interaction term into our main specification:

$$
\begin{aligned}
\text { EC Aid Re ceipts }(\log )_{j, t} & =\alpha+\beta_{1} \text { EC Aid Re ceipts }(\log )_{j, t-1}+\beta_{2} \text { Interest Coalition }_{j, t}+\beta_{3} \text { Heterogeneity }_{j, t} \\
+ & \beta_{4} \text { Per Capita GDP }(\log )_{j, t}+\beta_{5}\left(\text { Interest Coalition }^{*} \text { Heterogeneity }_{j, t}\right. \\
+ & \beta_{6}(\text { Per Capita GDP* Heterogeneity })_{j, t}+\beta_{7} \text { Controls }_{j, t}+\varepsilon_{j, t}
\end{aligned}
$$

Hypothesis 2a states that if interest heterogeneity increases, EU member states will be less likely to influence aid allocation, ceteris paribus $\left(\beta_{5}<0\right)$. We test this hypothesis using an interaction between Interest Coalition and Heterogeneity. Hypothesis $2 \mathrm{~b}$ states that as interest heterogeneity increases, economically needier countries will receive more aid, ceteris paribus $\left(\beta_{6}<0\right)$. We use an interaction between Per Capita GDP and Heterogeneity to test this hypothesis.

For all estimates, we present feasible generalized least squares (FGLS) regression estimates with a Prais-Winsten transformation accounting for first-order correlation within each panel and we report panel corrected standard errors to account for panel heteroskedasticity (Beck and Katz 1996). Because we have an unbalanced panel, we assume that the error variances are constant within each directed dyad, but heteroskedastic across dyads. Further, we include a lagged dependent variable (LDV) both for theoretical reasons and to deal with the possibility of first order serial correlation. Because we have a large $\mathrm{N}$ (146 recipient countries) and a large T (30 years) we follow Beck and Katz (2001) who show that the inclusion of a LDV deals with some of the problems from missing unit effects by capturing much of the variance that might otherwise be assigned to the covariates. ${ }^{25}$

25 The LDV along with the panel corrected standard errors goes some way towards dealing with the exclusion of fixed effects in our specification, but to verify that this is not a problem we re-estimate our model using ordinary least squares (OLS) with fixed effects in the robustness section. It is also possible that including a LDV in both our FGLS estimates and our OLS fixed effects estimates leads to biased coefficient estimates (Nickell 1981). The robustness section presents results of a model that uses the Arellano and Bond generalized method of moments (GMM) system estimator. Note, we do not employ this as our main specification technique because system 


\section{EMPIRICAL RESULTS}

Table 2 presents the results of our main hypothesis tests. We find that interest coalitions are an important determinant of European aid allocation. In addition, greater heterogeneity of EU member interests leads to an erosion of political influence on the aid allocation process, but to an increase in aid to poor recipient countries.

\section{[Table 2 about here]}

Model 1 examines the influence of dominant EU members (France and Germany) on European aid allocation (Hypothesis 1a). We find that the greater Germany's and France's interest in a recipient country, the more aid this recipient receives. Specifically, a one standard deviation increase in Dominant Donor (Germany) leads to an 8 percent increase in EU aid to that recipient. Similarly, a one standard deviation increase in Dominant Donor (France) leads to a 14 percent increase in EU multilateral aid. This finding supports our hypothesis that dominant members are able to influence the decision-making process within the EU and it demonstrates that past findings on the role of the US in the World Bank and IMF carry over to the EU. Model 2 analyzes the relationship between coalition support for a developing country within the Council and European aid receipts (Hypothesis 1b). Interest Coalition has a significant, positive influence on European aid receipts, providing support for our hypothesis that the greater coalition support within the EU for a developing country, the greater the recipient's aid receipts, regardless of its development needs. The substantive effect is large as well. A one standard deviation increase in Interest Coalition results in a 15 percent increase in European aid receipts.

[Figure 5 about here]

GMM was designed specifically for cases with many individuals and a small number of time periods and so in our case may not solve the possibility of correlation between the LDV and the error term (Roodman 2009). 
Model 3 examines the relationship between Council heterogeneity and the ability of EU members to influence European aid allocation (Hypothesis 2a). Since it is difficult to interpret the conditional effects directly we examine them graphically using the coefficient estimates and the variance-covariance matrices from Model 4. The solid line in Figure 5 shows the relationship between a one standard deviation increase in Interest Coalition on the amount of European aid allocated to each recipient as the preferences of EU members become more heterogeneous. The dotted lines represent the 95 percent confidence interval. The relationship is negative. As interest heterogeneity increases, the impact of interest coalitions on EU aid decreases. If preferences are very homogenous (for example at -2 , close to the minimum in our sample), a one standard deviation increase in Interest Coalition equates to an increase in aid flows to that recipient of nearly 20 percent. If preferences are very heterogeneous (for example, at 1.5 , the maximum in our sample), however, a one standard deviation increase in Interest Coalition equates to an increase of EU aid of only 6.5 percent. At the highest levels of heterogeneity, EU members can do little to affect the Commission's allocation of aid; the effect of interest coalitions on European arid allocation becomes insignificant.

\section{[Figure 6 about here]}

Model 4 analyzes the relationship between Council heterogeneity and the ability of the Commission to provide aid to the poorest countries (Hypothesis 2b). Figure 6 graphs the effect of a one percent increase in GDP per capita on EU Aid for different levels of Heterogeneity, holding all other variables constant. We find that the relationship between a country's income level (our proxy for development) and their EU aid receipts depends on the heterogeneity of member preferences. As the heterogeneity of interests increases, poor countries, on average, receive greater multilateral aid from the EU. When EU members have largely heterogeneous preferences (for example, at 1.5, the maximum in our sample), a one percent increase in a recipient's GDP would decrease its European aid receipts by nearly 60 percent. When EU 
member preferences are largely homogeneous (for example at -2 , close to the minimum in our sample), a one percent increase in the recipient's GDP would increase its European aid receipts by 7 percent. This provides support for Hypothesis $2 b$, that as the heterogeneity of EU member preferences increases, needier countries are more likely to receive EU multilateral aid. At the same time it indicates that EU members indeed have aid allocation preferences that are, on average, more strategic than the official EU development goals pursued by the European Commission.

Together, these results provide strong support for our theory. Interest coalitions play a central role in the allocation of European multilateral aid and it is important to analyze such coalitions and their interaction with the multilateral aid agent in order to get a fuller understanding of the politics of multilateral aid. The more powerful these coalitions are in the European Union, the greater their ability to bias the European aid allocation process in favor of their foreign policy goals. However, if EU member interests about aid goals diverge, the European Commission can play EU members against each other to pursue its own interests, which are more development oriented than those of the Council members. Although these findings provide some support for the general literature on agency slippage, it is important to discuss the unconditional relationship between interest heterogeneity and European aid flows as well. Independently, Heterogeneity has a negative and significant influence on European aid receipts. That is, on average recipients receive less aid if EU members' preferences about overall aid goals diverge. A one standard deviation increase in heterogeneity among EU members equates to a 29 percent decrease in overall aid. The effect is robust across all model specifications and indicates that interest heterogeneity within the EU may increase the Commission's ability to pursue the official EU aid goals, but contrary to the agency slippage argument, it does not increase the Commission's ability to expand the size of the European aid budget. We believe that this negative finding owes to the ability of EU governments to 
determine the size of their contributions. The findings then indicate that EU member states are less likely to delegate foreign aid to begin with if they expect to have little opportunity to bias aid in favor of their national interests.

Finally, we turn to our control variables. The coefficients of the variables that capture development needs point in the expected direction. The poorer the recipient and the greater its institutional quality, the greater its aid receipts from the EU (see, however, the conditional effect of GDP). African countries also tend to get more aid than Central and Eastern European countries (our excluded case), but there is no statistically significant difference between other regions of the world and Central and Eastern Europe. Our measures of strategic interest are also interesting. Former colonies receive greater aid, Distance, Imports from EU, and Population do not enter significantly into our model. Changes in aid, deaths from natural disasters, as well as the end of the Cold War all have a positive effect on aid receipts.

\section{ROBUSTNESS CHECKS}

Empirical results are often fragile to changes in model specification. To ensure that our results do not experience this same fragility we ran a number of robustness tests. For each test we use Equation 5, where we include both Interest Coalition and Heterogeneity, but exclude the interaction terms.

\section{Interest Coalition/Heterogeneity}

Our main independent variables, Interest Coalition and Heterogeneity, are based on the assumption that bilateral aid allocation patterns provide a good approximation to measure the aid allocation interests that EU members defend during Council negotiations. We can think of four potential problems with this measurement. First, bilateral aid allocation patterns are a function of both the strategic and development interests of EU member states. They are thus influenced by many of the control variables that we use in the main models, such as Trade, 
$G D P$, or Colony. This could be problematic for the interpretation of the results because these control variables could be capturing some part of our measure of interest. An alternative way to analyze the influence of interest saliency and bargaining power on European aid allocation is to estimate rather than measure Interest Saliency (Equation 1) based on the variables used in the extant empirical literature in a first stage regression and then use the predicted probabilities as an estimate of interest coalitions in the second stage. Specifically, we estimate the following first stage regression: ${ }^{26}$

$$
\begin{aligned}
& \text { EC Aid Receipts }(\log )_{i, j, t}=\alpha_{j}+\beta_{1} \operatorname{Im} \text { ports from EU }(\log )_{i, j, t}+\beta_{2}{\text { Dis } \tan c e_{i, j}} \\
& \qquad \beta_{3} \text { Alliance }_{i, j, t}+\beta_{4} \text { Colony }_{i, j}+\beta_{5} \operatorname{Re}_{\text {gion }}+\beta_{6} \text { Per Capita GDP }(\log )_{j, t} \\
& +\beta_{7}{\text { Institutional Quality }+\varepsilon_{j, t}}
\end{aligned}
$$

The predicted estimates from this equation represent the strategic and non-strategic determinants of bilateral aid, with the residual accounting for other factors that might influence the decision to give bilateral aid. In a second step, we use the predicted probabilities to calculate Interest Coalition and Heterogeneity and re-estimate Equation 5 excluding the control variables used in the first stage of Equation 7 (Imports from EU, Distance, Colony, Region, Per Capita GDP, and Institutional Quality):

$$
\begin{gathered}
\text { EC Aid Receipts }(\log )_{j, t}=\alpha+\beta_{1} \text { EC Aid Receipts }(\log )_{j, t-1}+\beta_{2} \text { Pr edicted Interest Coalition }{ }_{j, t} \\
+\beta_{3} \text { Heterogeneity }_{j, t}+\beta_{4} \text { Controls }+\varepsilon_{j, t}
\end{gathered}
$$

All models are estimated with corrected standard errors to account for the additional uncertainty introduced by the predictions. Model 5 in Table 3 presents the results, which are not significantly different from our main results in Table 1.

[Table 3 about here]

\footnotetext{
${ }^{26}$ All variables equivalent to those described in empirical section with the addition of Alliance which is equal to 1 in any year that the donor and recipient were in a military alliance, meaning a formal agreement for defensive action, offensive action, neutrality, non-aggression, or consultation regarding military conflict. Data from Leeds (2005).
} 
Second, whereas we argue that EU members aim to influence European aid allocation in the Council negotiations so as to achieve both their strategic and development objectives, it could be that the EU members' ability to assert themselves is different for these two dimensions of aid-giving. ${ }^{27}$ Specifically, EU member states may receive greater marginal returns per aid dollar if strategic interests are at stake because the EU member benefits from supporting development and achieves its foreign policy goals. On one hand, this could weaken its bargaining leverage in the Council negotiations leading to a weakening of the relationship between Interest Coalition and European aid allocation. On the other hand, it could induce the EU member to bargain even harder, leading to a strengthening of the relationship between Interest Coalition and European aid allocation. If this were true, then we would expect differences between the development-based portion and the strategic-based portion of an EU member's interests. Our bilateral aid measure cannot test for this directly because it includes both strategic and development interests. To account for the possibility that the relationship is different based on the type of interest, we calculated a measure of interest coalitions separating out these different motivations for aid. First, we substitute bilateral aid with voting affinity within the UN General Assembly, a measure used quite frequently in the literature to measure foreign policy alignment between two countries. Foreign policy alignment more likely represents the purely strategic portion of an EU member's interest in a recipient country. We calculated voting affinity or "S-Scores" between Council members and recipient countries from Voeten and Merdzanovic's UN voting data (Voeten and Merdzanovic 2009). Second, we replicated our two-stage estimation strategy in Equation 7, predicting bilateral aid in two components: (1) based only on the strategic interest of the donor and excluding development objectives (Per Capita GDP and Institutional Quality) and (2) based only on development

27 We thank one of our reviewers for pointing out this possibility. 
objectives. In the second stage we substituted these two predicted estimates for our measure of interest coalition.

Models 6 and 7 present the results. The relationship between Interest Coalition and European aid allocation remains positive and significant for both types of aid preferences. Further, according to the confidence intervals for both point estimates, there is no difference in magnitude between the two types of preferences. This could be because even though governments that have strategic interests might be less credible in the bargaining process, they have stronger incentives to bargain harder in order to better assert their preferences.

[Table 4 about here]

Third, the results for Interest Coalition could be driven by the influence of Germany and France, as two dominant members of the Council. To analyze whether this is the case, we excluded both France and Germany from our interest coalition variable (Table 4, Model 8), and included them separately. The main findings are robust to these changes.

Fourth, it could be that Council decisions are based on an informal negotiation process where the final decision takes into account the preferences of all EU members that have salient interests, regardless of their voting power (informal consensus voting). To test for this possibility we include Interest Coalition excluding the power component. ${ }^{28}$ Table 4, Model 9 shows that while Interest itself has a positive sign, it is not significant in our model. This implies that powerful coalitions have an advantage when attempting to bias EU multilateral aid allocations. ${ }^{29}$ This finding is very important for our theory as it provides the foundation for the importance of coalition dynamics in the European Union. At the same time, it provides

28 We thank Randy Stone for pointing out this possibility.

29 This is in line with theories of consensus bargaining in the European Union which shows that EU members take into account the formal power of each member when formulating a consensus decision. See for example Thomson et al. (2006). 
support for previous work on dominant donors since it shows that their influence is not simply due to saliency but also to their advantageous bargaining position.

\section{Estimation Technique}

[Table 5 about here]

Table 5 includes the results of a number of revised estimations. First, it is possible that the inclusion of the LDV does not deal with problems stemming from missing unit effects. To deal with this possibility we use OLS with fixed effects (both with and without LDV). Models 10 and 11 show that while the magnitude of the results changes, the signs and significance are retained. It is also possible that including a LDV in both our GLS estimates and our OLS fixed effects estimates results in biased coefficient estimates. We estimate a GMM model, which was specifically designed to deal with panel data that exhibits autocorrelation, to verify the robustness of our results (Arellano and Bond 1991, Kosack and Tobin 2006). Model 12 shows that there is a small difference in magnitude, but the results remain consistent. The SarganHansen test reports a p-value of one, indicating the possibility of over-fitting our endogenous variables. Finally, because many developing countries received no aid from the EU over many years we estimated our model using a time-series Tobit model. Model 13 presents these results, which again, contain minimal changes.

[Table 6 about here]

\section{Dependent Variable}

We further checked for the robustness of our results by estimating the main models with different operationalizations of the dependent variable. Table 6, Model 14 uses total aid allocation divided by the recipient's population (Aid Per Capita) and Model 15 uses the log of total aid allocation divided by the recipient country's GDP ( $\log$ of $A i d / G D P)$. Although the coefficient magnitudes change as a function of the different measurement, operationalizing the 
dependent variable differently does not significantly alter our results.

\section{Control Variables}

We also added different sets of control variables. The results are available upon request from the authors. First, we take out our colony variable and replace it with dummy variables for each of the colonial powers. Our main results do not change substantially. Interestingly, French and British colonies receive more aid than non-colonies, while Spanish and Italian colonies receive less aid than non-colonies (Belgian and Portuguese colonies are not significantly different from non-colonies). Second, we included an alternative measure of institutional quality. Institutional quality is inherently difficult to measure as a concept. Although a number of proxies currently exist, few do so over a long time-period for many countries. We use political risk, a commonly used measure available from the International Country Risk Guide (ICRG). It is measured on a scale from 1 to 100 with higher numbers signaling better levels of the political environment in a country (that is, lower levels of political risk). Because of limited time availability, we lose over 1,000 observations from the inclusion of this variable. It remains insignificant in the model, but does nothing to significantly alter the overall results of our specification. Third, we included a variable equal to one in any year that a country experienced a financial crisis. This variable was insignificant in each of our models and did not have a significant impact on our results. Fourth, a main target of EU development assistance has traditionally been the group of African, Caribbean, and Pacific (ACP) countries. Including an ACP dummy does not change the results. Fifth, we include fixed time effects into the model. They do not substantively affect the main results. Sixth, we control for the fact that beginning in 2004 many Central and Eastern European countries became ineligible for European aid because they joined the EU. We both included a dummy variable equal to 1 in every year that a country was a member of the EU and dropped each country-year from our analysis. Again, this had no significant impact on our results. 


\section{Outliers}

The results in this paper could be unduly affected by outliers. For example, Turkey over the last few years has received an increasingly large share of EU aid. We examined the means and standard deviations of the variables themselves to check for anything unusual, and we employed a number of standard regression diagnostics, including cooks distances, dfbetas, and added-variable plots. The tests revealed very few disproportionately influential observations: only Turkey from 2002-2006, the Czech Republic from 2002-2003, and Romania from 20012004 stood out. Removing these had no effect on the results, and thus we retained them in our estimation.

\section{CONCLUSION}

The EU is the largest multilateral aid donor in the world, yet scant attention has been paid to how and why it allocates its foreign aid resources. We argued that the allocation of EU multilateral aid is influenced by how decision-making processes within the Council translate into the ability of EU members to bias the Commission's aid policies towards their foreign aid interests. If aid allocation interests in the Council converge, EU multilateral aid is likely to be biased towards the interests of its dominant members or powerful interest coalitions. If interests in the Council diverge, then the Commission can play the interests of EU members against each other and allocate aid to the poorest countries. However, at the same time, it will face declining financial resources to do so because EU members' willingness to delegate their foreign aid through the Commission declines. The empirical analysis provides robust support for our theory.

The paper provides a first analysis of collective principal dynamics in the European Union and it also provides new insights for decision-making processes and multilateral aid allocation in general. First, we show that influence in multilateral aid allocation is not limited to the most 
dominant donors, but that weak states can form powerful interest coalitions that do have an effect on aid allocation. Interestingly, we find that power does matter and that EU members can not rely on informal bargaining to assert their interests. Second, whereas principal-agent theories typically expect an increase in the organizational budget if the principals' preferences diverge, we show that the Commission actually has fewer resources at its disposal in such situations. This finding is a consequence of allowing EU members to substitute multilateral aid-giving with bilateral aid-giving. A decline in their influence then triggers a decline in the amount of resources they delegate to these institutions.

There are several reasons as to why we believe that our theory is applicable beyond the EU to other multilateral aid institutions as well. First, our theory applies to institutions that delegate at least some management and agenda-setting powers to a multilateral agent. Virtually all multilateral aid institutions have some form of delegation of financial resources to a multilateral agent who, in turn, has some capacity to independently manage and implement aid allocation. Second, our theory applies to institutions which grant influence to governments. Intergovernmental bodies serve to control agents and to determine the overall goals of that institution. All multilateral aid institutions have these bodies and whereas agents in the IMF or the World Bank typically have greater independence in the implementation and management of development projects, they are constrained by the decisions of the Board of Executive Directors. Third, our theory is flexible to various institutional frameworks. For example, we expect that the influence of interest groups would diminish with the restrictiveness of the decision-making rules within the intergovernmental decision-making body. If members have to decide by unanimity, then they can bias the multilateral aid agent only if they possess enough informal bargaining power to by-pass other members and directly influence the agent. Woods (2003), for example, shows that the United States has such informal influence in the staff of the IMF and the World Bank. Fourth, our theory is flexible to the asymmetry of its 
members' decision-making power.

Our paper focuses on the ability of interest coalitions to influence who gets European aid. One interesting venue for future research would be to analyze the ability of interest coalitions to influence how European aid is spent. For example, the EU has imposed positive conditionality in many of its aid projects where recipients are more likely to receive aid if they have strong records of good governance. The European Commission and EU member states could have diverging preferences about whether and to what extent conditionality should be applied in these cases. We expect that our general theory of interest coalitions would hold, but it could be important to analyze the interests of the Council and the Commission on the one hand, and variations in such interests across Council members on the other.

The decision to give foreign aid has never been one based solely on altruism. Yet the primary rationale behind delegating management and agenda-setting powers to the EU has been to ensure a more development-based approach to foreign aid. In a time of redesign of the multilateral aid institutions to ensure greater efficiency and impact on those countries most in need, our theory speaks to the possibility for reform. If reforms are able to better insulate multilateral aid agencies from the strategic designs of their members, multilateral aid agencies will be better able to achieve their goals of reaching the poorest countries. Nevertheless, the question remains of how much delegation is possible before governments lose their incentive to delegate aid to the international level to begin with. 


\section{BIBLIOGRAPHY}

Alesina, Alberto and David Dollar, 2000: Who Gives Foreign Aid and to Whom and Why?, in: Journal of Economic Growth, 5:33-63.

Arellano, Manuel, and Stephen Bond, 1991: Some Tests of Specification for Panel Data: Monte Carlo Evidence and an Application to Employment Equations, in: The Review of Economic Studies, 58: 277.

Baumann, Martin, Jean-Claude Berthelemy, and Katharina Michaelowa, 2010: Von Lomé bis Cotonou: Der Stellenwert von Armutsbekämpfung und guter Regierungsführung in der Entwicklungspolitik der Europäischen Union zwischen 1980 und 2006. Unpublished Working Paper.

Beck, Nathaniel and Jonathan N. Katz, 1996: Nuisance vs. Substance: Specifying and Estimating Time-Series-Cross-Section Models, in: Political Analysis 6: 1-36.

Beck, Nathaniel and Jonathan N. Katz, 2001: Throwing Out the Baby with the Bath Water: A Comment on Green, Kim, and Yoon, in: International Organization 55: 487-495.

Carbone, Maurizio, 2007: The European Union and International Development. The Politics of Foreign Aid. Routledge.

Copelovitch, Mark S., 2010: Master or Servant? Common Agency and the Political Economy of IMF Lending, International Studies Quarterly 54(1): 49-77.

Easterly, William and David Dollar, 1999: The Search for the Key: Aid, Investment, and Policies in Africa," Journal of African Economies 8 (4):546-577.

Easterly, William, Ross Levine, and David Roodman, 2004: Aid, Policies, and Growth: Comment, in: American Economic Review 94: 774-780.

EU Commission, 2002: The European Development Fund in a Few Word, Luxembourg: Office for Official Publications of the European Communities. 
EU Commission, 2010: EU Contribution to the Millennium Development Goals. Some Key Results from European Commission Programmes. Brussels: European Commission.

Faini, Riccardo and Enzo Grilli, 2004: Who Runs the IFIs? CEPR Working Paper No. 4666.

Frey, Bruno S., 1997: The Public Choice of International Organizations, in: Dennis Mueller (ed.) Perspectives on Public Choice. Cambridge: Cambridge University Press.

Gleditsch, Kristian S. and Michael D. Ward, 2001: Measuring Space: A Minimum-Distance Database and Applications to International Studies, in: Journal of Peace Research 47: 697-709.Grilli, Enzo R., 1994: The European Community and the Developing Countries, Cambridge: Cambridge University Press.

Grilli, Enzo, 1993: The European Community and the Developing Countries. Cambridge: Cambridge University Press.

Hawkins, Darren G., David A. Lake, Daniel L. Nielson, and Michael J. Tierney, 2006: Delegation and Agency in International Organizations. Cambridge: Cambridge University Press.

Kosack, Stephen and Jennifer Tobin, 2006: Funding Self-sustaining Development: The Role of Aid, FDI and Government in Economic Success, in: International Organization, 60: 205-243.

Kostadinova, Petia, 2009: EU Development and Pre-accession Aid: The Role of EU Institutions and Economic Interest. Unpublished Working Paper.

Leeds, Brett Ashley. 2005. "The Alliance Treaty Obligations and Provisions Project." Accessed February 2, 2010, at http://atop.rice.edu/.

Lyne, Mona M., Daniel L. Nielson, and Michael J. Tierney, 2009: Controlling Coalitions: Social Lending at Multilateral Development Banks, in: The Review of International Organizations 4(4): 407-433. 
Maizels, Alfred and Machiko K. Nissanke, 1984: Motivations for Aid to Developing Countries, in: World Development 12(9): 879-900.

March. James and Johan Olsen, 1998, The Institutional Dynamics of International Political Orders, in: International Organization 52: 943-969.

Marshall, Monty, Keith Jaggers, and Ted Gurr, 2009: The Polity IV Project: Political Regime Characteristics and Transitions, 1800-2007.

Tierney (eds.) Delegation and Agency in International Organizations. Cambridge: Cambridge University Press, p107-139.

Nickell, Stephen, 1981: Biases in Dynamic Models with Fixed Effects, in: Econometrica 49: $1417-1426$

Nielson, Daniel L. and Michael J. Tierney, 2003: Delegation to International Organizations: Agency Theory and World Bank Environmental Reform, in: International Organization 57(2): 241-276.

Nielson, Daniel L. and Michael J. Tierney, 2010: Principals and Interests: Common Agency and Multilateral Development Bank Lending. Unpublished Working Paper.

Rodrik, Dani, 1995: Why is there Multilateral Lending. NBER Working Paper No. 5160.

Roodman, David, 2009: How to do xtabond2: An introduction to difference and system GMM in Stata, in: Stata Journal, 9(1):86-136.

Schoultz, L., 1982: Politics, Economics, and US Participation in Multilateral Development Banks, in: International Organization 36: 537-574.

Schraeder, Peter J., Steven W. Hook, and Bruce Taylor, 1998: Clarifying the Foreign Aid Puzzle: A Comparison of American, Japanese, French, and Swedish Aid Flows, in: World Politics 50(2): 294-323.

Stone, Randall W., 2002: Lending Credibility. The International Monetary Fund and the PostCommunist Transition. Princeton: Princeton University Press. 
Stone, Randall W., 2004: The Political Economy of IMF Lending in Africa, in: American Political Science Review 98(4): 577-591.

Stone, Randall W., 2008: The Scope of IMF Conditionality, in: International Organization 62: 589-620.

Stone, Randall 2011: Controlling Institutions: International Organizations and the Global Economy. Cambridge: Cambridge University Press

Thacker, Strom, 1999: The High Politics of IMF Lending, in: World Politics 52: 38-75.

Thomson, Robert, Frans N. Stokman, Christopher H. Achen, and Thomas Koenig, 2006: The European Union Decides. Cambridge: Cambridge University Press.

Tsoutsoplides, Constantine, 1991: The Determinants of the Geographical Allocation of EC Aid to the Developing Countries, in: Applied Economics 23: 647-658.

Vaubel, Roland, 1996: Bureaucracy at the IMF and the World Bank, in: The World Economy 19(2): 195-210.

Vaubel, Roland, 2006: Principal-Agent Problems in International Organizations, in: Review of International Organizations 1: 125-138.

Voeten, Eric and Adis Merdzanovic, 2009: "United Nations General Assembly Voting Data", http://hdl:1902.1/12379UNF:3:Hpf6qOkDdzzvXF9m66yLTg==V1

Woods, Ngaire, 2003: The United States and the International Financial Institutions: Power and Influence within the World Bank and the IMF, in: Foot, McFarlane and Mastanduno (eds.) US Hegemony and International Organizations, p. 92-114.

Zanger, Sabine C., 2000: Good Governance and European Aid: The Impact of Political Conditionality, in: European Union Politics 1(3): 293-317. 
Figure 1: Delegation to Multilateral Aid Institutions in Millions Constant (2009) US\$

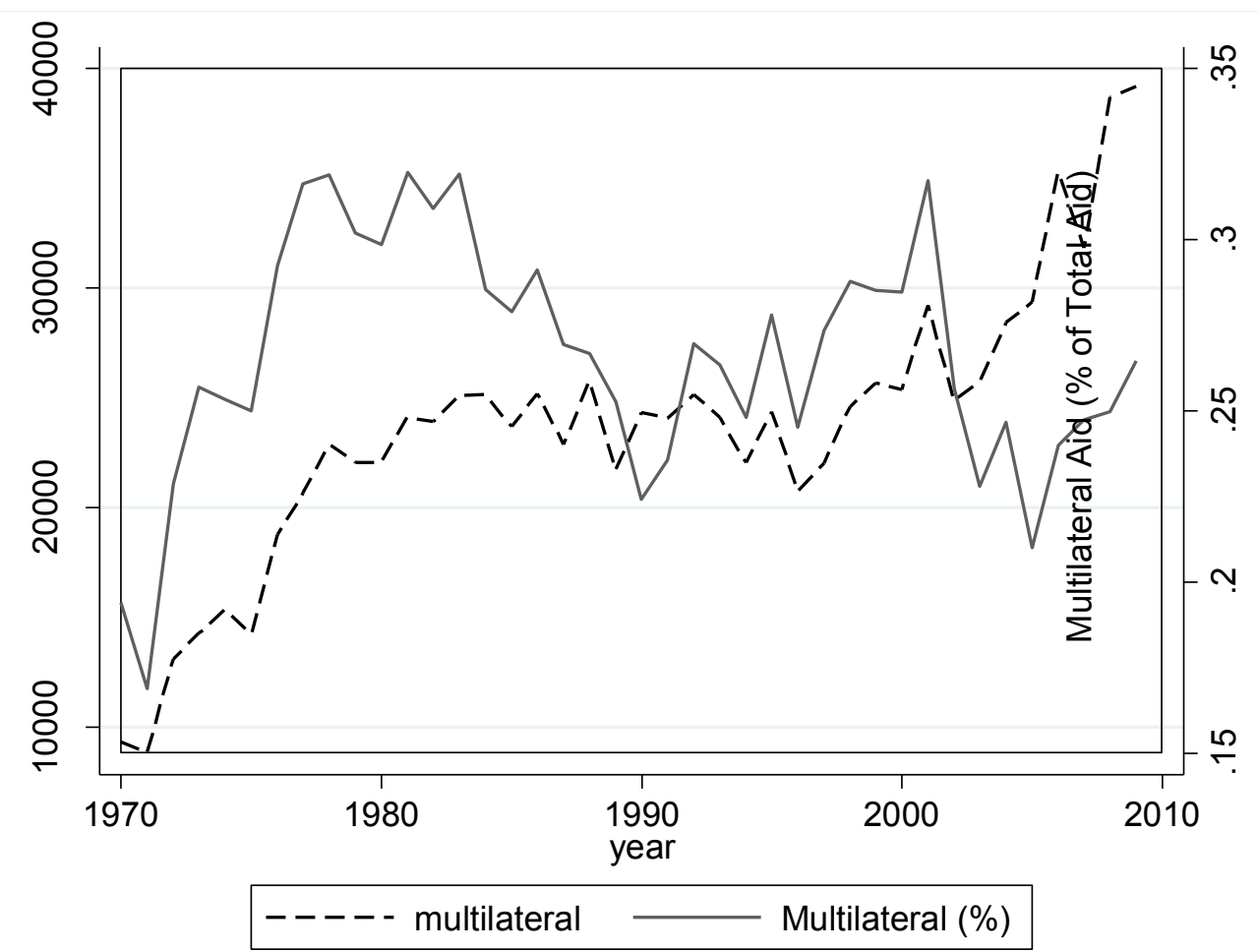


Figure 2: Total Aid Flows in Millions Constant (2000) US\$

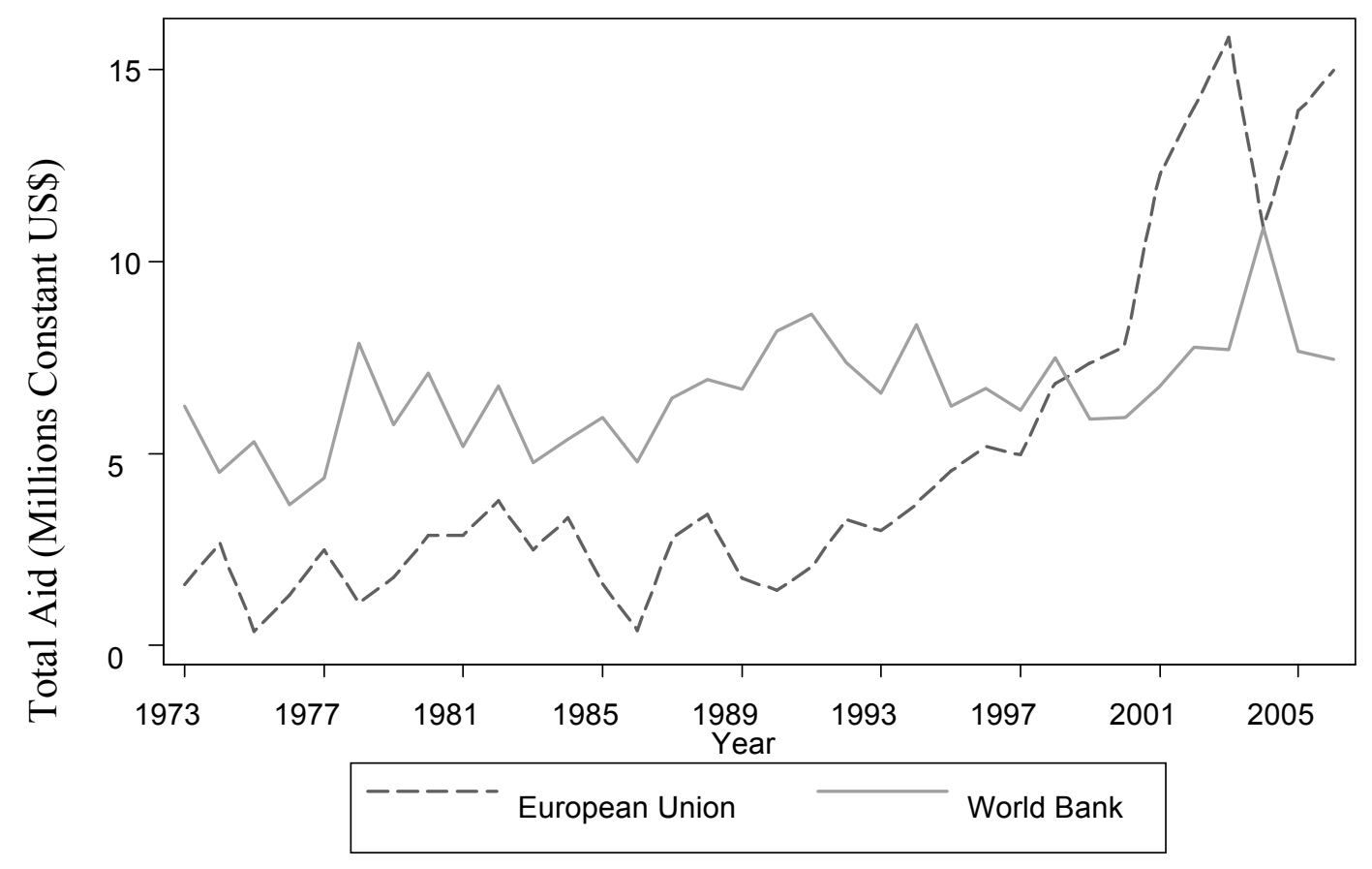


Figure 3: Interest Coalitions by Region

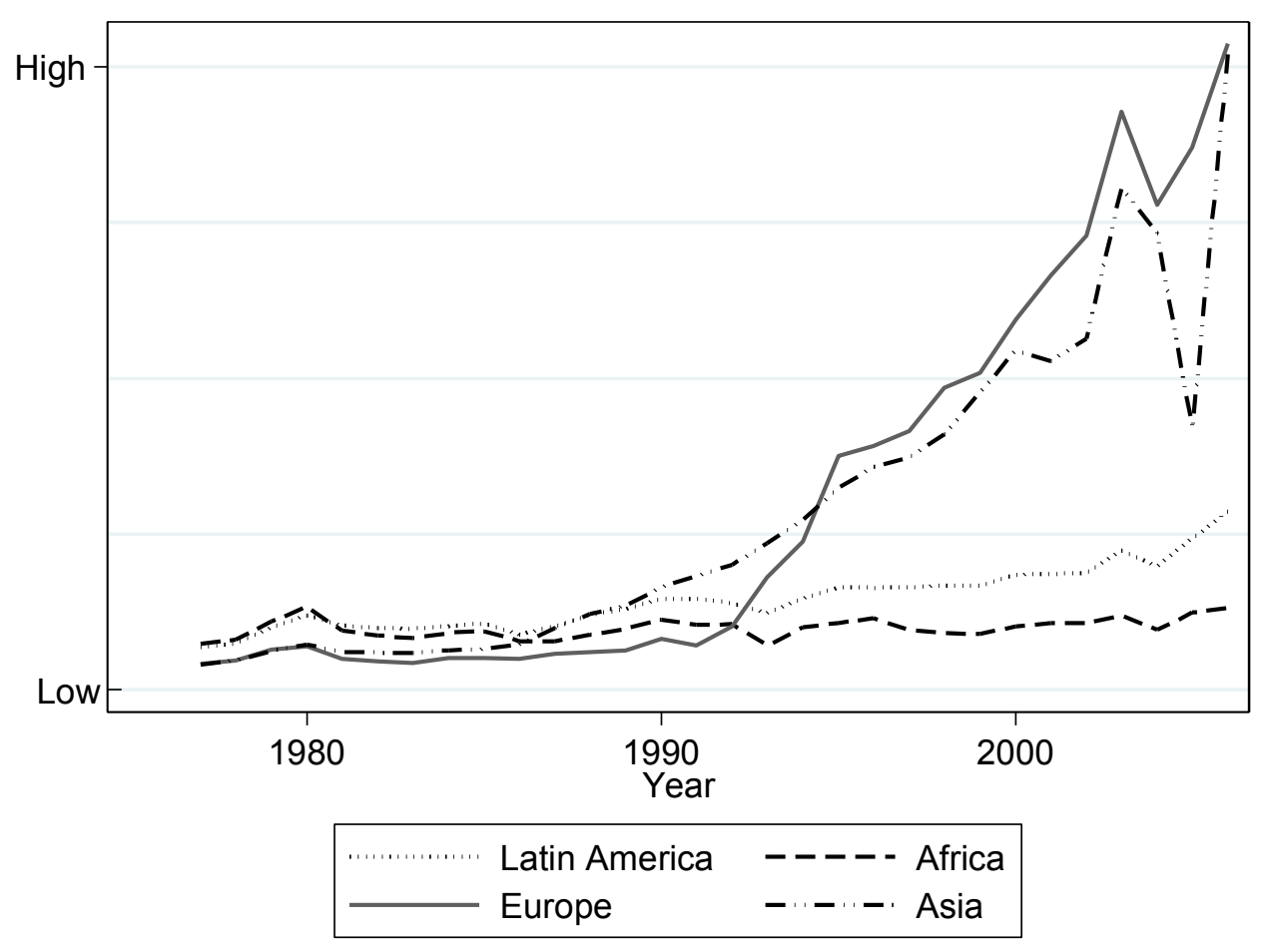


Figure 4: Interest Coalitions, Selected African Countries

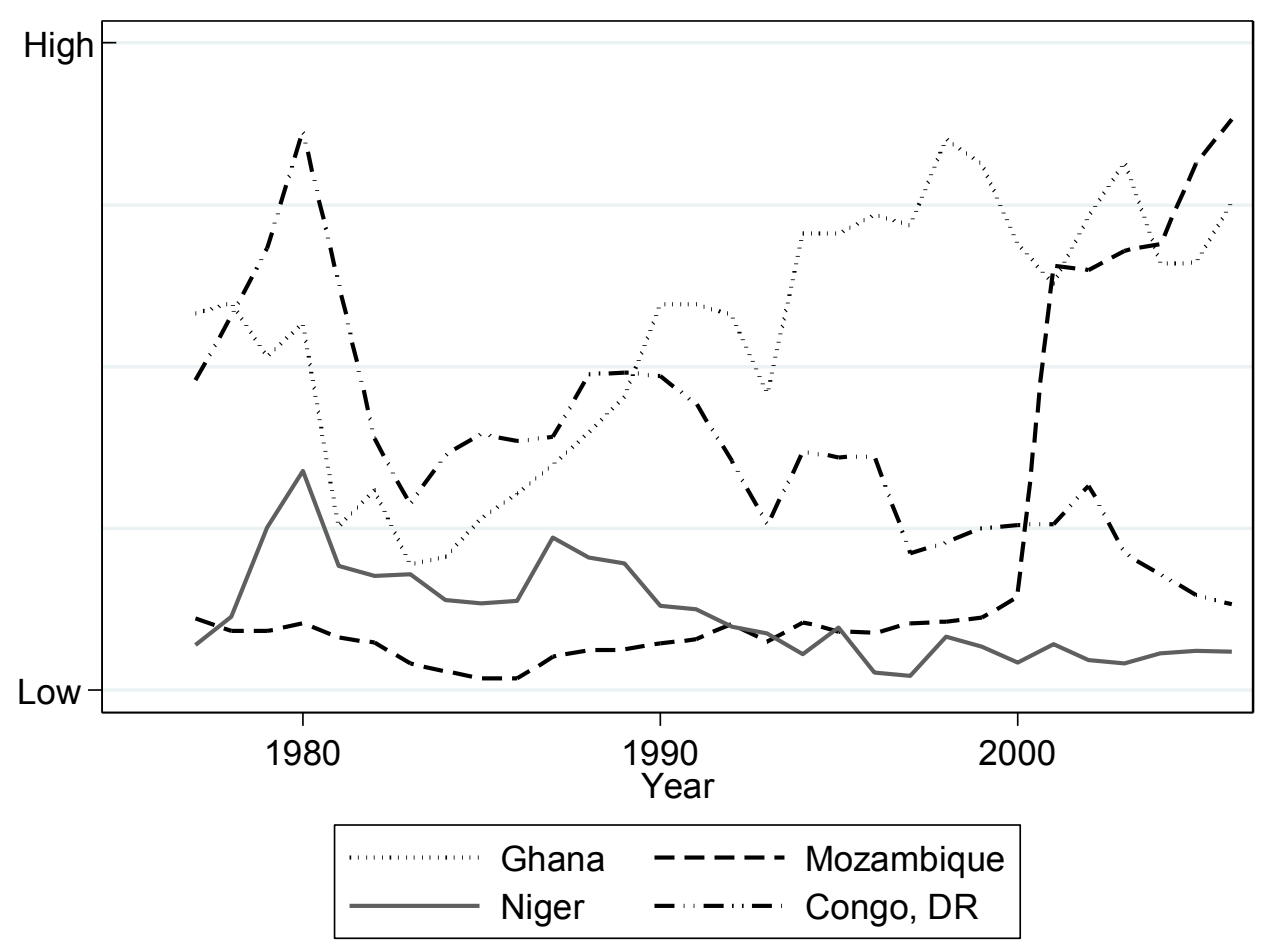


Figure 5: Effect of an Increase in Interest Coalition on EU Multilateral Aid for Varying Levels of Heterogeneity

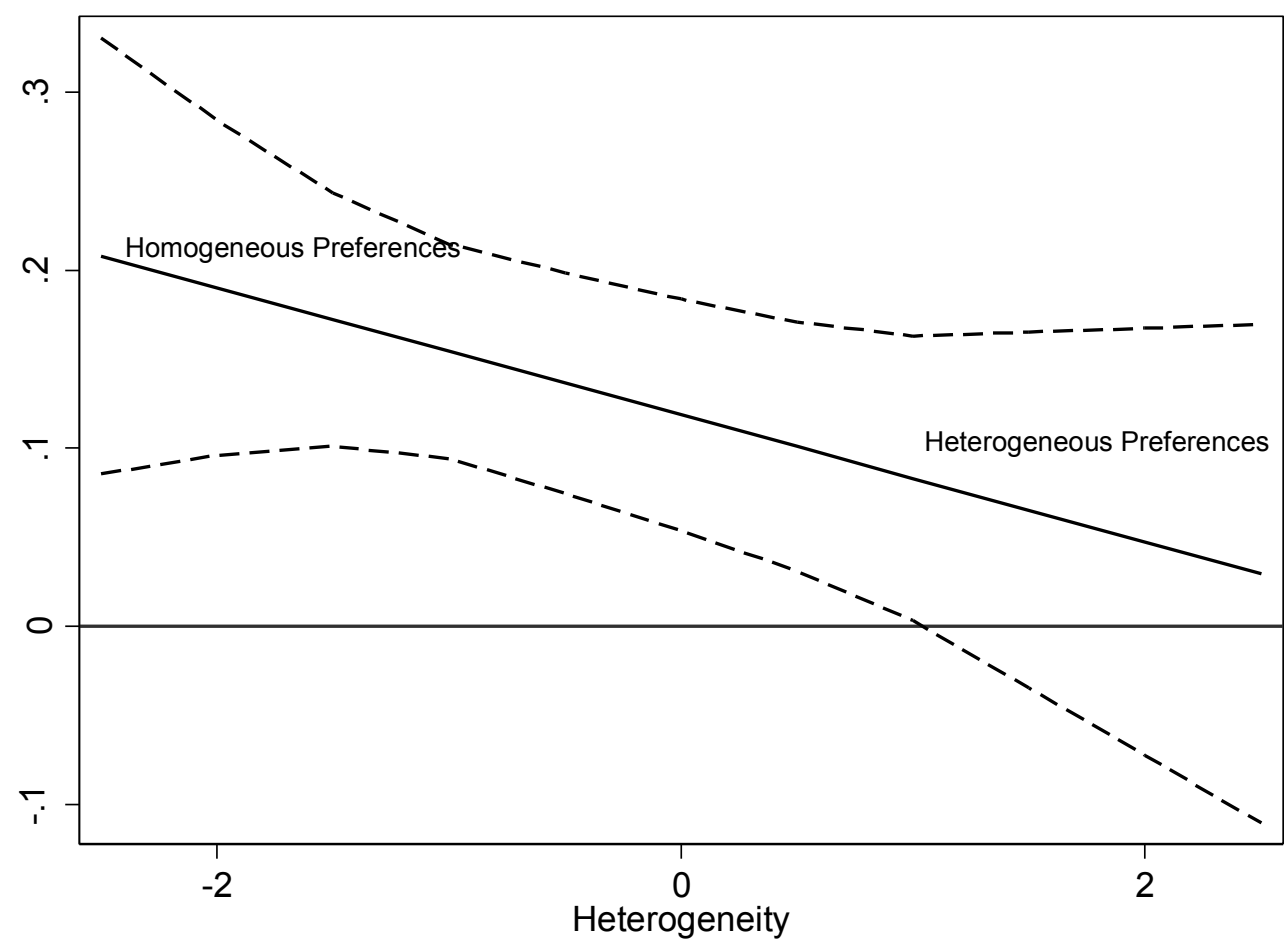


Figure 6: Effect of an Increase in GDP on EU Multilateral Aid for Varying Levels of Heterogeneity

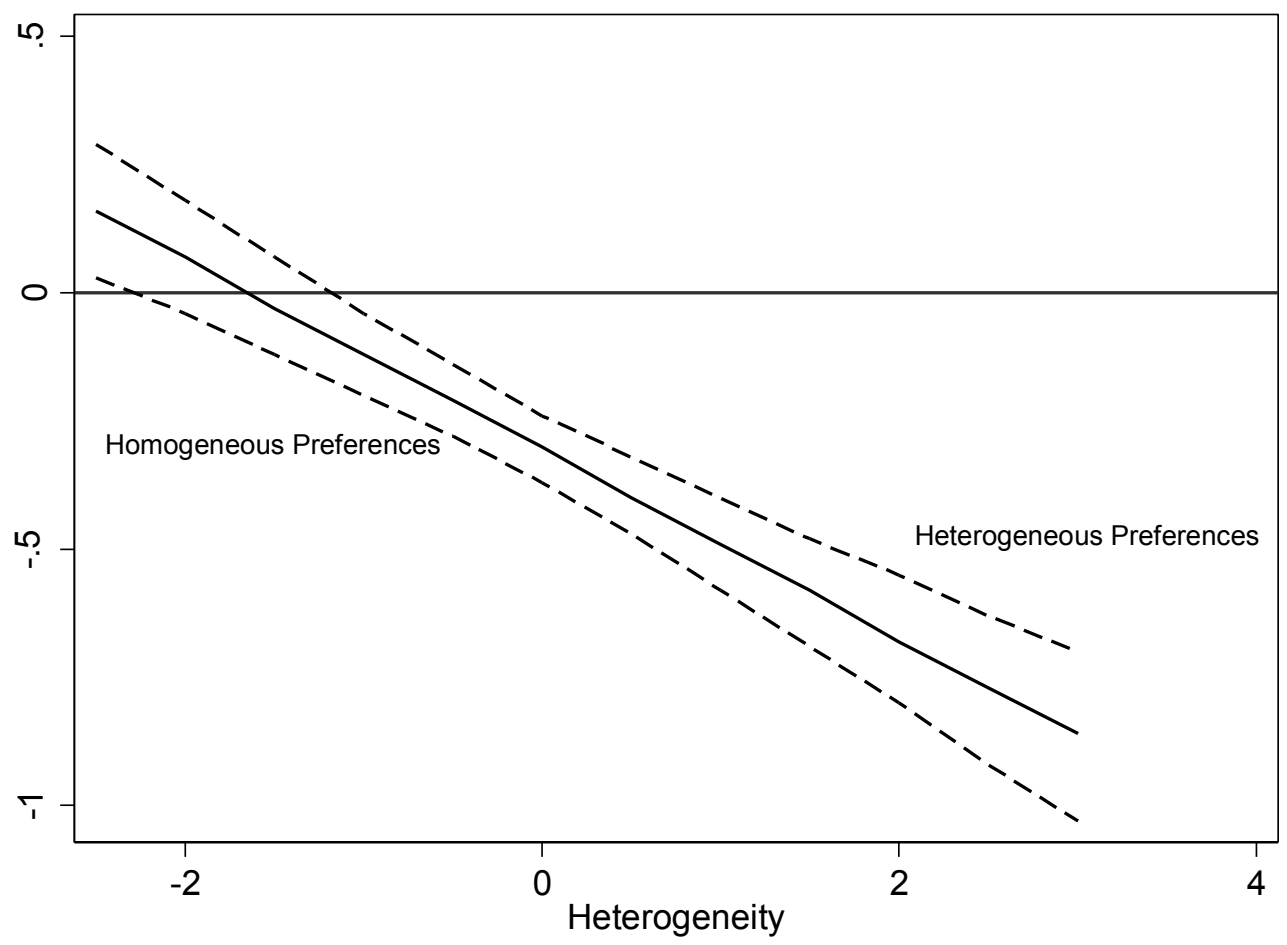


Table 1: Descriptive Statistics

\begin{tabular}{lcrrrr}
\hline \multicolumn{1}{c}{ Variable } & $N$ & Mean & \multicolumn{1}{c}{ SD } & Min & \multicolumn{1}{c}{ Max } \\
\hline EC Aid Receipts (log) & 5007 & 5.81 & 4.75 & 0 & 14.72 \\
Interest Coalition & 5007 & 0 & 1 & -0.33 & 30.21 \\
Heterogeneity & 4033 & 0 & 1 & -2.26 & 1.50 \\
Per Capita GDP (log) & 4062 & 7.08 & 1.26 & 4.03 & 10.41 \\
Sub Saharan Africa & 5007 & 0.29 & 0.46 & 0 & 1 \\
Middle East \& North Africa & 5007 & 0.06 & 0.24 & 0 & 1 \\
Asia & 5007 & 0.26 & 0.44 & 0 & 1 \\
Latin America \& Caribbean & 5007 & 0.22 & 0.41 & 0 & 1 \\
Colony & 5007 & 0.71 & 0.46 & 0 & 1 \\
Distance (log) & 5007 & 67.70 & 36.22 & 7.22 & 164.95 \\
Imports from EU (log) & 4467 & 11.20 & 4.44 & -0.30 & 18.22 \\
Population (log) & 4860 & 15.16 & 2.08 & 9.89 & 20.99 \\
Natural Disaster Deaths & 4857 & 422 & 6818 & 0 & 300000 \\
EU Aid Change (\%) & 5007 & 3.44 & 16.53 & -55.33 & 45.27 \\
Institutional Quality & 3942 & 9.15 & 6.87 & 0 & 20 \\
\hline
\end{tabular}


Table 2: Interest Coalitions and EU Multilateral Aid

\begin{tabular}{|c|c|c|c|c|}
\hline DV: EC Aid Receipts (log) & Model 1 & Model 2 & Model 3 & Model 4 \\
\hline Interest Coalition & & $\begin{array}{l}0.154 * * * \\
(0.059)\end{array}$ & $\begin{array}{l}0.119^{\wedge} \\
(0.088)\end{array}$ & $\begin{array}{l}0.134^{* *} \\
(0.059)\end{array}$ \\
\hline Dominant Donor (Germany) & $\begin{array}{l}0.082 * * \\
(0.041)\end{array}$ & & & \\
\hline Dominant Donor (France) & $\begin{array}{l}0.142 * * * \\
(0.045)\end{array}$ & & & \\
\hline Heterogeneity & $\begin{array}{l}-0.299 * * * \\
(0.065)\end{array}$ & $\begin{array}{l}-0.288 * * * \\
(0.065)\end{array}$ & $\begin{array}{l}-0.284 * * * \\
(0.065)\end{array}$ & $\begin{array}{l}0.972 * * * \\
(0.320)\end{array}$ \\
\hline Per Capita GDP $(\log )$ & $\begin{array}{l}-0.253 * * * \\
(0.064)\end{array}$ & $\begin{array}{l}-0.285^{* * * *} \\
(0.066)\end{array}$ & $\begin{array}{l}-0.280^{* * * *} \\
(0.067)\end{array}$ & $\begin{array}{l}-0.305^{* * *} \\
(0.067)\end{array}$ \\
\hline Heterogeneity*Coalition & & & $\begin{array}{l}-0.036^{\wedge} \\
(0.068)\end{array}$ & \\
\hline Heterogeneity*GDP & & & & $\begin{array}{l}-0.186 * * * \\
(0.048)\end{array}$ \\
\hline Lagged Dependent Variable & $\begin{array}{l}0.602 * * * \\
(0.016)\end{array}$ & $\begin{array}{l}0.603 * * * \\
(0.016)\end{array}$ & $\begin{array}{l}0.602 * * * \\
(0.016)\end{array}$ & $\begin{array}{l}0.600 * * * \\
(0.016)\end{array}$ \\
\hline Sub Saharan Africa & $\begin{array}{l}0.279 \\
(0.266)\end{array}$ & $\begin{array}{l}0.244 \\
(0.267)\end{array}$ & $\begin{array}{l}0.240 \\
(0.268)\end{array}$ & $\begin{array}{l}0.310 \\
(0.267)\end{array}$ \\
\hline Middle East \& North Africa & $\begin{array}{l}-0.480 \\
(0.305)\end{array}$ & $\begin{array}{l}-0.445 \\
(0.309)\end{array}$ & $\begin{array}{l}-0.457 \\
(0.311)\end{array}$ & $\begin{array}{l}-0.429 \\
(0.307)\end{array}$ \\
\hline Asia & $\begin{array}{l}-0.596^{*} \\
(0.314)\end{array}$ & $\begin{array}{l}-0.592^{*} \\
(0.314)\end{array}$ & $\begin{array}{l}-0.605^{*} \\
(0.316)\end{array}$ & $\begin{array}{l}-0.573^{*} \\
(0.314)\end{array}$ \\
\hline Latin America \& Caribbean & $\begin{array}{l}-0.927 * * * \\
(0.297)\end{array}$ & $\begin{array}{l}-0.974 * * * \\
(0.298)\end{array}$ & $\begin{array}{l}-0.987 * * * \\
(0.300)\end{array}$ & $\begin{array}{l}-0.956^{* * * *} \\
(0.298)\end{array}$ \\
\hline Colony & $\begin{array}{l}0.353^{*} \\
(0.206)\end{array}$ & $\begin{array}{l}0.556^{* * *} \\
(0.205)\end{array}$ & $\begin{array}{l}0.555^{* * *} * \\
(0.205)\end{array}$ & $\begin{array}{l}0.562 * * * \\
(0.204)\end{array}$ \\
\hline Distance $(\log )$ & $\begin{array}{l}0.001 \\
(0.003)\end{array}$ & $\begin{array}{l}-0.001 \\
(0.003)\end{array}$ & $\begin{array}{l}-0.001 \\
(0.003)\end{array}$ & $\begin{array}{l}-0.001 \\
(0.003)\end{array}$ \\
\hline Imports from EU (log) & $\begin{array}{l}0.022 \\
(0.016)\end{array}$ & $\begin{array}{l}0.024 \\
(0.016)\end{array}$ & $\begin{array}{l}0.024 \\
(0.016)\end{array}$ & $\begin{array}{l}0.020 \\
(0.016)\end{array}$ \\
\hline Population (log) & $\begin{array}{l}-0.046 \\
(0.043)\end{array}$ & $\begin{array}{l}-0.046 \\
(0.044)\end{array}$ & $\begin{array}{l}-0.038 \\
(0.046)\end{array}$ & $\begin{array}{l}-0.022 \\
(0.044)\end{array}$ \\
\hline Natural Disaster Deaths & $\begin{array}{l}0.885 \\
(0.568)\end{array}$ & $\begin{array}{l}0.814 \\
(0.563)\end{array}$ & $\begin{array}{l}0.816 \\
(0.562)\end{array}$ & $\begin{array}{l}0.891 \\
(0.566)\end{array}$ \\
\hline EU Aid Change (\%) & $\begin{array}{l}0.016 * * * \\
(0.003)\end{array}$ & $\begin{array}{l}0.016 * * * \\
(0.003)\end{array}$ & $\begin{array}{l}0.016 * * * \\
(0.003)\end{array}$ & $\begin{array}{l}0.016^{* * *} \\
(0.003)\end{array}$ \\
\hline Institutional Quality & $\begin{array}{l}0.021 * * \\
(0.010)\end{array}$ & $\begin{array}{l}0.020 * * \\
(0.010)\end{array}$ & $\begin{array}{l}0.021 * * \\
(0.010)\end{array}$ & $\begin{array}{l}0.018^{*} \\
(0.010)\end{array}$ \\
\hline Time Trend & $\begin{array}{l}-0.025^{* *} \\
(0.012)\end{array}$ & $\begin{array}{l}-0.027 * * \\
(0.012)\end{array}$ & $\begin{array}{l}-0.027 * * \\
(0.012)\end{array}$ & $\begin{array}{l}-0.026^{* * *} \\
(0.012)\end{array}$ \\
\hline Post Cold War & $\begin{array}{l}1.222 * * * \\
(0.199)\end{array}$ & $\begin{array}{l}1.222 * * * \\
(0.199)\end{array}$ & $\begin{array}{l}1.222 * * * \\
(0.199)\end{array}$ & $\begin{array}{l}1.229 * * * \\
(0.199)\end{array}$ \\
\hline Constant & $\begin{array}{l}53.213 * * \\
(23.799)\end{array}$ & $\begin{array}{l}57.904 * * \\
(23.872)\end{array}$ & $\begin{array}{l}57.494 * * \\
(23.863)\end{array}$ & $\begin{array}{l}56.854 * * \\
(23.776)\end{array}$ \\
\hline Number of Observations & 2959 & 2959 & 2959 & 2957 \\
\hline Number of Recipients & 123 & 123 & 123 & 123 \\
\hline $\mathrm{R}^{2}$ & 0.60 & 0.59 & 0.59 & 0.60 \\
\hline
\end{tabular}

Notes: Equations 5 \& 6 by FGLS;

Standard errors in parentheses; * significant at $10 \% ; * *$ significant at $5 \% ; * * *$ significant at $1 \%$; $\wedge$ jointly significant at $10 \%$ 
Table 3: Robustness Checks, Interest Coalitions I

Model $5 \quad$ Model $6 \quad$ Model 7

Predicted Estimates UN S-Scores Predicted Estimates

for Interest (strategic for Interest for Interest and non-strategic)

\begin{tabular}{llll}
\hline Interest Coalition (predicted estimates) & $\begin{array}{l}0.516^{* * *} \\
(0.056)\end{array}$ & \\
Heterogeneity (predicted estimates) & $-0.590^{* * *}$ & \\
& $(0.102)$ & \\
Interest Coalition (UN S-Score) & & $0.485^{* * *}$ & \\
& & $(0.076)$ & \\
Heterogeneity (UN S-Score) & & $-0.219^{* *}$ & \\
& & $(0.096)$ & \\
Interest Coalition & & $0.371^{* * *}$ \\
(predicted estimates strategic interest) & & $(0.063)$ \\
Heterogeneity & & $-0.607^{* * *}$ \\
(predicted estimates strategic interest) & & $(0.095)$ \\
Interest Coalition & & $0.497^{* * *}$ \\
(predicted estimates development interest) & & $(0.063)$ \\
Heterogeneity & & $-0.527^{* * *}$ \\
(predicted estimates development interest) & & $(.0655)$ \\
Per Capita GDP (log) & & & \\
& & & \\
Lagged Dependent Variable & $0.660^{* * *}$ & $(0.060)$ & $0.612^{* * *}$ \\
& $(0.015)$ & $0.608^{* * *}$ & $(0.016)$ \\
Constant & $-119.321^{* * *}$ & -6.028 & $98.864^{* * *}$ \\
& $(40.473)$ & $(26.458)$ & $(28.004)$ \\
\hline Number of Observations & 2939 & 3213 & 2939 \\
Number of Recipients & 126 & 122 & 126 \\
$\mathrm{R}^{2}$ & 0.61 & 0.61 \\
\hline
\end{tabular}

Notes: Equation 5 by FGLS; Standard errors in parentheses; Control Variables omitted to save space.

* significant at $10 \%$; $*$ significant at $5 \% ; * * *$ significant at $1 \%$ 
Table 4: Robustness Checks, Interest Coalitions II

\begin{tabular}{|c|c|c|}
\hline DV: EC Aid Receipts (log) & Model 8 & Model 9 \\
\hline Dominant Donor (Germany) & $\begin{array}{l}0.069^{*} \\
(0.040)\end{array}$ & \\
\hline Dominant Donor (France) & $\begin{array}{l}0.147 * * * \\
(0.045)\end{array}$ & \\
\hline Coalition (Excluding France \& Germany) & $\begin{array}{l}0.134 * * \\
(0.058)\end{array}$ & \\
\hline Interest Saliency (Excluding Power) & & $\begin{array}{l}0.081 \\
(0.053)\end{array}$ \\
\hline Lagged Dependent Variable & $\begin{array}{l}0.609 * * * \\
(0.015)\end{array}$ & $\begin{array}{l}0.618 * * * \\
(0.015)\end{array}$ \\
\hline Per Capita GDP (log) & $\begin{array}{l}-0.442^{* * *} \\
(0.063)\end{array}$ & $\begin{array}{l}-0.404 * * * \\
(0.062)\end{array}$ \\
\hline Sub Saharan Africa & $\begin{array}{l}0.484 * * \\
(0.245)\end{array}$ & $\begin{array}{l}0.474 * \\
(0.246)\end{array}$ \\
\hline Middle East \& North Africa & $\begin{array}{l}-0.102 \\
(0.277)\end{array}$ & $\begin{array}{l}-0.140 \\
(0.278)\end{array}$ \\
\hline Asia & $\begin{array}{l}-0.344 \\
(0.274)\end{array}$ & $\begin{array}{l}-0.326 \\
(0.274)\end{array}$ \\
\hline Latin America \& Caribbean & $\begin{array}{l}-0.487^{*} \\
(0.273)\end{array}$ & $\begin{array}{l}-0.592 * * \\
(0.273)\end{array}$ \\
\hline Colony & $\begin{array}{l}0.700 * * * \\
(0.198)\end{array}$ & $\begin{array}{l}0.824 * * * \\
(0.194)\end{array}$ \\
\hline Distance $(\log )$ & $\begin{array}{l}-0.000 \\
(0.003)\end{array}$ & $\begin{array}{l}-0.000 \\
(0.003)\end{array}$ \\
\hline Imports from EU (log) & $\begin{array}{l}0.044 * * * * \\
(0.015)\end{array}$ & $\begin{array}{l}0.050 * * * \\
(0.014)\end{array}$ \\
\hline Population (log) & $\begin{array}{l}-0.045 \\
(0.042)\end{array}$ & $\begin{array}{l}0.010 \\
(0.040)\end{array}$ \\
\hline Natural Disaster Deaths & $\begin{array}{l}0.953 * \\
(0.575)\end{array}$ & $\begin{array}{l}0.848 \\
(0.567)\end{array}$ \\
\hline EU Aid Change (\%) & $\begin{array}{l}0.014 * * * \\
(0.003)\end{array}$ & $\begin{array}{l}0.015 * * * \\
(0.003)\end{array}$ \\
\hline Institutional Quality & $\begin{array}{l}0.023 * * \\
(0.009)\end{array}$ & $\begin{array}{l}0.022 * * \\
(0.009)\end{array}$ \\
\hline Time Trend & $\begin{array}{l}-0.023 * * \\
(0.012)\end{array}$ & $\begin{array}{l}-0.025^{* *} \\
(0.012)\end{array}$ \\
\hline Post Cold War & $\begin{array}{l}1.494 * * * \\
(0.193)\end{array}$ & $\begin{array}{l}1.489 * * * \\
(0.193)\end{array}$ \\
\hline Constant & $\begin{array}{l}50.363 * * \\
(22.859)\end{array}$ & $\begin{array}{l}52.115^{* *} \\
(22.849)\end{array}$ \\
\hline Number of Observations & 3217 & 3217 \\
\hline $\mathrm{R}^{2}$ umber of Recipients & $\begin{array}{l}123 \\
064\end{array}$ & $\begin{array}{l}123 \\
064\end{array}$ \\
\hline
\end{tabular}

Notes: Equation 5 by FGLS; Standard errors in parentheses;

$*$ significant at $10 \% ;{ }^{* *}$ significant at $5 \% ; * * *$ significant at $1 \%$ 
Table 5: Robustness Checks, Model Specification

\begin{tabular}{|c|c|c|c|c|}
\hline DV: EC Aid Receipts (log) & $\begin{array}{l}\text { Model } 10 \\
\text { OLS, FE }\end{array}$ & $\begin{array}{l}\text { Model } 11 \\
\text { OLS, FE }\end{array}$ & $\begin{array}{l}\text { Model } 12 \\
\text { GMM } \\
\text { System }\end{array}$ & $\begin{array}{c}\text { Model } 13 \\
\text { Tobit }\end{array}$ \\
\hline Interest Coalition & $\begin{array}{l}0.202 * * * \\
(0.071)\end{array}$ & $\begin{array}{l}0.334 * * * \\
(0.078)\end{array}$ & $\begin{array}{l}0.188 * * * \\
(0.061)\end{array}$ & $\begin{array}{l}0.213 * * * \\
(0.062)\end{array}$ \\
\hline Heterogeneity & $\begin{array}{l}-0.273 * * * \\
(0.081)\end{array}$ & $\begin{array}{l}-0.410 * * * \\
(0.089)\end{array}$ & $\begin{array}{l}-0.416^{* * * *} \\
(0.082)\end{array}$ & $\begin{array}{l}-0.340 * * * \\
(0.072)\end{array}$ \\
\hline Per Capita GDP $(\log )$ & $\begin{array}{l}0.010 \\
(0.258)\end{array}$ & $\begin{array}{l}0.008 \\
(0.284)\end{array}$ & $\begin{array}{l}-0.313 * * * \\
(0.087)\end{array}$ & $\begin{array}{l}-0.342 * * * \\
(0.091)\end{array}$ \\
\hline Lagged Dependent Variable & $\begin{array}{l}0.405 * * * \\
(0.017)\end{array}$ & & $\begin{array}{l}0.558 * * * \\
(0.024)\end{array}$ & $\begin{array}{l}0.508 * * * \\
(0.018)\end{array}$ \\
\hline Sub Saharan Africa & & & $\begin{array}{l}0.301 \\
(0.276)\end{array}$ & $\begin{array}{l}0.434 \\
(0.325)\end{array}$ \\
\hline Middle East \& North Africa & & & $\begin{array}{l}-0.404 \\
(0.389)\end{array}$ & $\begin{array}{l}-0.571 \\
(0.370)\end{array}$ \\
\hline Asia & & & $\begin{array}{l}-0.662 * \\
(0.343)\end{array}$ & $\begin{array}{l}-0.652^{*} \\
(0.365)\end{array}$ \\
\hline Latin America \& Caribbean & & & $\begin{array}{l}-1.195 * * * \\
(0.416)\end{array}$ & $\begin{array}{l}-1.096^{* * *} \\
(0.362)\end{array}$ \\
\hline Colony & & & $\begin{array}{l}0.524 * * \\
(0.241)\end{array}$ & $\begin{array}{l}0.681^{* * *} \\
(0.240)\end{array}$ \\
\hline Distance $(\log )$ & & & $\begin{array}{l}-0.002 \\
(0.004)\end{array}$ & $\begin{array}{l}-0.001 \\
(0.004)\end{array}$ \\
\hline Imports from EU (log) & $\begin{array}{l}0.091 * * \\
(0.039)\end{array}$ & $\begin{array}{l}0.138^{* * *} \\
(0.043)\end{array}$ & $\begin{array}{l}0.038 \\
(0.025)\end{array}$ & $\begin{array}{l}0.047^{*} \\
(0.027)\end{array}$ \\
\hline Population (log) & $\begin{array}{l}-6.006^{* * *} \\
(0.816)\end{array}$ & $\begin{array}{l}-10.264 * * * \\
(0.877)\end{array}$ & $\begin{array}{l}-0.077 \\
(0.058)\end{array}$ & $\begin{array}{l}-0.077 \\
(0.058)\end{array}$ \\
\hline Natural Disaster Deaths & $\begin{array}{l}0.506 \\
(0.673)\end{array}$ & $\begin{array}{l}0.633 \\
(0.741)\end{array}$ & $\begin{array}{l}0.596^{*} \\
(0.358)\end{array}$ & $\begin{array}{l}0.742 \\
(0.676)\end{array}$ \\
\hline EU Aid Change (\%) & $\begin{array}{l}0.015 * * * \\
(0.003)\end{array}$ & $\begin{array}{l}0.011^{* * *} \\
(0.003)\end{array}$ & $\begin{array}{l}0.019 * * * \\
(0.003)\end{array}$ & $\begin{array}{l}0.015 * * * \\
(0.003)\end{array}$ \\
\hline Institutional Quality & $\begin{array}{l}-0.017 \\
(0.015)\end{array}$ & $\begin{array}{l}-0.035^{* *} \\
(0.017)\end{array}$ & $\begin{array}{l}0.044 * * * \\
(0.009)\end{array}$ & $\begin{array}{l}0.017 \\
(0.011)\end{array}$ \\
\hline Time Trend & $\begin{array}{l}0.134 * * * \\
(0.024)\end{array}$ & $\begin{array}{l}0.287 * * * \\
(0.025)\end{array}$ & & $\begin{array}{l}-0.012 \\
(0.013)\end{array}$ \\
\hline Post Cold War & $\begin{array}{l}1.445^{* * *} \\
(0.212)\end{array}$ & $\begin{array}{l}1.603 * * * \\
(0.234)\end{array}$ & & $\begin{array}{l}1.195 * * * \\
(0.213)\end{array}$ \\
\hline Constant & $\begin{array}{l}-167.58 * * * \\
(36.658)\end{array}$ & $\begin{array}{l}-402.64 * * * \\
(38.951)\end{array}$ & $\begin{array}{l}5.759 * * * \\
(1.126) \\
\end{array}$ & $\begin{array}{l}28.458 \\
(25.945) \\
\end{array}$ \\
\hline Number of Observations & 2959 & 2959 & 2959 & 2959 \\
\hline $\begin{array}{l}\text { Number of Recipients } \\
\mathrm{R}^{2}\end{array}$ & $\begin{array}{l}123 \\
0.36\end{array}$ & $\begin{array}{l}123 \\
0.23\end{array}$ & 123 & 123 \\
\hline
\end{tabular}

Notes: Equation 5 by various methods; Standard errors in parentheses;

* significant at $10 \%$;* significant at $5 \%$; ** significant at $1 \%$ 
Table 6: Robustness Checks, Dependent Variable

\begin{tabular}{|c|c|c|}
\hline & $\begin{array}{c}\text { Model } 14 \\
\text { DV: } \\
\text { Aid Per } \\
\text { Capita }\end{array}$ & $\begin{array}{c}\text { Model } 15 \\
\text { DV: } \\
\text { Log of } \\
\text { Aid/GDP }\end{array}$ \\
\hline Interest Coalition & $\begin{array}{l}0.032 \\
(0.020)^{*}\end{array}$ & $\begin{array}{l}0.098 * * \\
(0.039)\end{array}$ \\
\hline Heterogeneity & $\begin{array}{l}-0.149 * * * \\
(0.039)\end{array}$ & $\begin{array}{l}-0.130 * * * \\
(0.035)\end{array}$ \\
\hline Per Capita GDP $(\log )$ & $\begin{array}{l}-0.092^{* *} \\
(0.041)\end{array}$ & $\begin{array}{l}-0.616^{* * *} \\
(0.044)\end{array}$ \\
\hline Lagged Dependent Variable & $\begin{array}{l}0.412 * * * \\
0.022\end{array}$ & $\begin{array}{l}0.500 * * * \\
(0.018)\end{array}$ \\
\hline Sub Saharan Africa & $\begin{array}{l}-0.367 * * \\
(0.153)\end{array}$ & $\begin{array}{l}0.103 \\
(0.141)\end{array}$ \\
\hline Mid East \& North Africa & $\begin{array}{l}-0.271 \\
(0.174)\end{array}$ & $\begin{array}{l}-0.103 \\
(0.142)\end{array}$ \\
\hline Asia & $\begin{array}{l}-0.653^{* * *} \\
(0.170)\end{array}$ & $\begin{array}{l}-0.494 * * * \\
(0.159)\end{array}$ \\
\hline Latin America \& Caribbean & $\begin{array}{l}-0.880^{* * *} \\
(0.174)\end{array}$ & $\begin{array}{l}-0.461 * * * \\
(0.156)\end{array}$ \\
\hline Colony & $\begin{array}{l}0.317 * * * \\
(0.110)\end{array}$ & $\begin{array}{l}0.328 * * * \\
(0.096)\end{array}$ \\
\hline Distance $(\log )$ & $\begin{array}{l}-0.004 * * \\
(0.002)\end{array}$ & $\begin{array}{l}-0.002 \\
(0.002)\end{array}$ \\
\hline Imports from EU $(\log )$ & $\begin{array}{l}-0.004 \\
(0.011)\end{array}$ & $\begin{array}{l}0.006 \\
(0.011)\end{array}$ \\
\hline Population (log) & $\begin{array}{l}-0.412 * * * \\
(0.032)\end{array}$ & $\begin{array}{l}0.072 * * * \\
(0.026)\end{array}$ \\
\hline Natural Disaster Deaths & $\begin{array}{l}0.120 \\
(0.254)\end{array}$ & $\begin{array}{l}0.446 \\
(0.305)\end{array}$ \\
\hline EU Aid Change (\%) & $\begin{array}{l}0.008 * * * \\
(0.002)\end{array}$ & $\begin{array}{l}0.009 * * * \\
(0.002)\end{array}$ \\
\hline Institutional Quality & $\begin{array}{l}0.023 * * * \\
(0.006)\end{array}$ & $\begin{array}{l}0.016^{* * *} \\
(0.005)\end{array}$ \\
\hline Time Trend & $\begin{array}{l}-0.015^{* *} \\
(0.007)\end{array}$ & $\begin{array}{l}0.014 * * \\
(0.007)\end{array}$ \\
\hline Post Cold War & $\begin{array}{l}-0.120 \\
(0.126)\end{array}$ & $\begin{array}{l}0.136 \\
(0.107)\end{array}$ \\
\hline Constant & $\begin{array}{l}-26.392 * \\
(14.632)\end{array}$ & $\begin{array}{l}-24.793^{*} \\
(13.167)\end{array}$ \\
\hline Number of Observations & 2107 & 2874 \\
\hline Number of Recipients & 120 & 122 \\
\hline $\mathrm{R}^{2}$ & 0.53 & 0.66 \\
\hline
\end{tabular}




\section{Mortara Working Paper Series}

For the full list, visit http://mortara.georgetown.edu/papers/

Address: Mortara Center for International Studies, Georgetown University, $3600 \mathrm{~N}$ Street, NW, Washington, DC 20057.

Lim, Daniel Yew Mao and James Raymond Vreeland. 2011. Regional Organizations and International Politics: Trading Asian Development Bank Loans for United Nations Security Council Votes. Georgetown University, Mortara Center Working Paper 2011-1.

Oldenski, Lindsey. 2010. Export Versus FDI: A Task-Based Approach. Georgetown University, Mortara Center Working Paper 2011-2.

Oldenski, Lindsey. 2011. The Task Composition of Offshoring by U.S. Multinationals. Georgetown University, Mortara Center Working Paper 2011-3.

Owen, Erica and Dennis Quinn. 2011. Does Economic Globalization Influence the U.S. Policy Mood?: A Study of U.S. Public Sentiment, 1956-2008. Georgetown University, Mortara Center Working Paper 2011-4.

Gete, Pedro. Housing Markets and Current Account Dynamics. 2010. Georgetown University, Mortara Center Working Paper 2011-5.

Fair, Christine C, Karl Kaltenhaler and William J. Miller. 2011. Iranians and the Bomb: Tales from the Demand Side. Georgetown University, Mortara Center Working Paper 2011-6.

Blair, Graeme et al. 2011. Poverty and Support for Militant Politics: Evidence from Pakistan. Georgetown University, Mortara Center Working Paper 2011-7.

Fair, Christine C., Neil Malhotra and Jacob N. Shapiro. 2011. Democratic Values and Support for Militancy: Evidence from a National Survey of Pakistan. Georgetown University, Mortara Center Working Paper 2011-8.

Dreher, Alex and James Raymond Vreeland. Buying Votes and International Organizations. Georgetown University, Mortara Center Working Paper 2011-9.

Kroenig, Matthew and Michael Weintraub. 2011. The Nuclear Balance and International Conflict. Georgetown University, Mortara Center Working Paper 2011-10. 